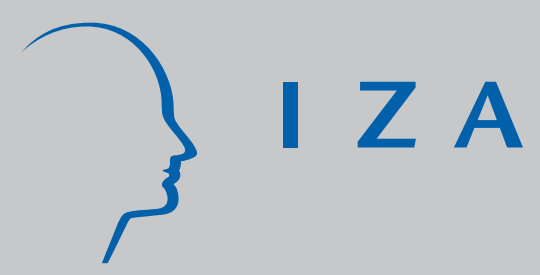

IZA DP No. 432

Employment, Wages, and Alcohol Consumption in Russia: Evidence from Panel Data

Erdal Tekin

February 2002 


\title{
Employment, Wages, and Alcohol Consumption in Russia: Evidence from Panel Data
}

\author{
Erdal Tekin \\ Department of Economics, Andrew Young School of Policy Studies, \\ Georgia State University and IZA, Bonn
}

Discussion Paper No. 432

February 2002

\author{
IZA \\ P.O. Box 7240 \\ D-53072 Bonn \\ Germany \\ Tel.: +49-228-3894-0 \\ Fax: +49-228-3894-210 \\ Email: iza@iza.org
}

This Discussion Paper is issued within the framework of IZA's research area Labor Markets in Transition Countries. Any opinions expressed here are those of the author(s) and not those of the institute. Research disseminated by IZA may include views on policy, but the institute itself takes no institutional policy positions.

The Institute for the Study of Labor (IZA) in Bonn is a local and virtual international research center and a place of communication between science, politics and business. IZA is an independent, nonprofit limited liability company (Gesellschaft mit beschränkter Haftung) supported by the Deutsche Post AG. The center is associated with the University of Bonn and offers a stimulating research environment through its research networks, research support, and visitors and doctoral programs. IZA engages in (i) original and internationally competitive research in all fields of labor economics, (ii) development of policy concepts, and (iii) dissemination of research results and concepts to the interested public. The current research program deals with (1) mobility and flexibility of labor, (2) internationalization of labor markets, (3) the welfare state and labor markets, (4) labor markets in transition countries, (5) the future of labor, (6) evaluation of labor market policies and projects and (7) general labor economics.

IZA Discussion Papers often represent preliminary work and are circulated to encourage discussion. Citation of such a paper should account for its provisional character. A revised version may be available on the IZA website (www.iza.org) or directly from the author. 
IZA Discussion Paper No. 432

February 2002

\title{
ABSTRACT \\ Employment, Wages, and Alcohol Consumption in Russia: Evidence from Panel Data*
}

This paper examines the effects of alcohol consumption on employment and wages for males and females in Russia. Both cross sectional and fixed-effects models are estimated utilizing data from the Russia Longitudinal Monitoring Survey. The results from the models that do not control for unobserved heterogeneity indicate that alcohol consumption has a positive impact on employment and wages. Further, there is some evidence in favor of an inverse U-shaped relationship between alcohol consumption and the labor market outcomes. Once the unobserved heterogeneity is controlled for using fixed effects, the positive association diminishes for the employment models for males and females. For the wage models, controlling for unobserved heterogeneity strengthens the positive impact of alcohol consumption both in significance and magnitude for males, while the reverse is true for females. However, the inverse U-shaped relationship obtained in cross-sectional models no longer exists. The results underline that unobserved heterogeneity plays an important role on the relationship between alcohol consumption and labor market behavior for both males and females. The findings are robust to model specifications and various alcohol consumption measures.

JEL Classification: J10, J20

Keywords: Employment, wages, alcohol consumption, Russia

\author{
Erdal Tekin \\ Department of Economics \\ Andrew Young School of Policy Studies \\ Georgia State University \\ University Plaza \\ Atlanta, GA 30303 \\ USA \\ Email: tekin@gsu.edu \\ Tel.: +1 $404651-3968$ \\ Fax: +1 404 651-4985 \\ Email: tekin@gsu.edu
}

\footnotetext{
* The author thanks David Blau, Julie Hotchkiss, Michael Grossman, and Naci Mocan for their helpful comments and discussions.
} 


\section{Introduction}

Concerns about the economic implications of the relationship between alcohol consumption and labor market productivity are well grounded. If problem drinking or alcoholism is considered as a disease, then it may have depressant effects on labor market productivity, resulting in reductions in employment, earnings, and other labor market outcomes (Rice et al., 1990; Kenkel and Ribar, 1994; Mullahy and Sindelar 1993 and 1996). On the other hand, there exists vast evidence in the medical literature that has documented a U-shaped relationship between alcohol consumption and the risk of cardiovascular disease. This implies that moderate drinkers should have a lower risk of cardiovascular disease than either abstainers or heavy drinkers (Boffetta and Garfinkel, 1990; Shaper, 1990; Marmot and Brunner, 1991; Beaglehole and Jackson, 1992; Coate, 1993; Doll et al., 1994). Consistent with this evidence, several economists found a positive association between moderate drinking and earnings (Berger and Leigh, 1988; Cook, 1991; French and Zarkin, 1995; Heien, 1996; Zarkin et al., 1998; Hamilton and Hamilton, 1997; MacDonald and Shields, 2001).

This paper investigates the impact of alcohol consumption on employment and wages for males and females in Russia. The primary contributions of the paper are twofold. First, it enhances the economic literature by employing a longitudinal data set and estimating fixed-effects models of the effect of alcohol consumption on employment and wages. This method avoids the potential bias that would stem from the unobserved individual factors not captured in previous research. This is a significant issue because causality is difficult to establish as alcohol use may be correlated with unobserved individual factors that would also influence labor market outcomes. The use of fixed effects method is an important departure from the literature because the data sets used in previous studies are cross-sectional and usually lack adequate variables that could serve 
as identifying instruments to control for the endogeneity of alcohol consumption. ${ }^{1}$ In addition, the richness of the data set used in this paper allows the use of three alternative measures of alcohol consumption in the empirical analysis. Specifically, alcohol consumption is measured as both discrete indicators and a continuous variable defined by the amount of ethanol consumed. This is important since the relationship between alcohol consumption and labor market outcomes may be sensitive to the alcohol measures used.

The second notable contribution of this paper is that it provides the first evidence on the association between alcohol consumption and the labor market outcomes in Russia. Excessive alcohol consumption is a widespread problem in Russia, where forty percent of men and seventeen percent of women suffer from alcoholism according to the figures disclosed from the Russia's Health Ministry. There have been several attempts to tackle the problem of alcoholism in Russia in the past. One of the earlier and probably the most well-known attempt was by Mikhail Gorbachev, who pursued a strenuous campaign against alcoholism in the mid-1980s. Although it was well intentioned, the campaign was a political disaster for Gorbachev, and his government had to relax its stringent measures against alcohol consumption and sales. The most recent attempt was an increase in the excise tax rate on alcohol by forty percent in 2000 . However, the announcement caused panic among consumers who formed long lines outside distillers to stock up, and regional governments refused to implement this new measure fearing civil disobedience (CNN Interactive: Russian Elections, 2000).

Using data from the Russia Longitudinal Monitoring Survey (RLMS), benchmark cross-sectional models similar to those used in previous studies are estimated first as an

\footnotetext{
${ }^{1}$ The only exception is Kenkel and Ribar (1994) who exploited the longitudinal nature of NLSY. However, their measure of alcohol consumption was heavy drinking, which is different from the one used in this paper.
} 
attempt to replicate their findings. The results from these models confirm the positive association between alcohol consumption and the labor market behavior documented in earlier studies. Consistent with the previous studies, cross-sectional results usually support the hypothesis of an inverse U-shaped relationship between alcohol consumption and wages and employment. Fixed-effect models generate drastically different results in comparison to those obtained from cross-section models, underlining the importance of accounting for unobserved heterogeneity. Consequences of controlling for unobserved heterogeneity are shown to be different for males and females. The positive effect of alcohol consumption on employment of males disappeared for males and weakened for females. The impact on wages on the other hand, strengthened for males and again weakened for females once the heterogeneity is controlled for.

The remainder of this paper is organized as follows. Section II reviews the previous evidence on the effects of alcohol consumption on labor market outcomes. Section III provides a discussion of the conceptual issues and the empirical strategy. Section IV introduces the data set and provides descriptive information. Section V reports the estimation results and discusses the sensitivity of the results to several diagnostic checks. Section VI concludes the paper.

\section{Previous Evidence}

There is a considerable literature on the impact of alcohol consumption and alcoholism on labor market behavior. The vast majority of this literature concentrates on the United States, mainly due to data limitations. Exceptions are the studies by Hamilton and Hamilton (1997) and MacDonalds and Shields (2001). Hamilton and Hamilton (1997) explored the relationship between alcohol consumption and annual earnings for

prime-age males using data of Canadian workers. The authors estimated wage equations 
for abstainers, moderate, and heavy drinkers using both OLS and a multinomial logit model, accounting for the possible selection into drinking status. They found that moderate alcohol consumption leads to increased earnings relative to both abstention and heavy drinking. MacDonald and Shields (2001) investigated the impact of alcohol consumption on occupational attainment (defined as the mean hourly wage for each occupation) using data from the Health Survey for England. The authors addressed the possible endogeneity of alcohol consumption using an instrumental variables (IV) method. Their results suggest that there exists an inverse U-shaped relationship between alcohol consumption and mean occupational wages.

For the literature pertaining to United States, Berger and Leigh (1988) is one of the first studies to consider the relationship between alcohol use and labor market productivity. The authors used data from the 1972-73 U.S. Quality of Employment Survey to examine the relationship between alcohol consumption and wages. Estimating separate wage equations for drinkers and non-drinkers, and accounting for selection into drinking status, the authors found that drinkers earn higher wages than non-drinkers. They used variables indicating the repetitiveness of the job and obesity as identifying instruments. However, it is questionable whether these variables are valid instruments as they may also affect earnings.

French and Zarkin (1995) investigated the relationship between alcohol consumption and wages for workers, using a sample of employees at four worksites. Using a continuous measure of alcohol consumption (defined by the number of drinks in the past 12 months), the authors estimated wage equations with OLS. To test for a possible nonlinear relationship between alcohol consumption and wages, they included the quadratic, and cubic forms of drinking as well as the linear measure in their equations. They could not address the potential endogeneity of alcohol consumption due 
to a lack of appropriate instruments in their data set. Under the assumption of exogenous alcohol use, they found evidence of an inverse U-shaped relationship between drinking and wages. Following this paper, Zarkin et al. (1998) tested whether the inverse Ushaped relationship could be replicated on a national sample of workers from the 1991 and 1992 National Household Survey of Drug Abuse. The authors found some evidence for an inverse U-shaped association between alcohol use and wages at low drinking levels for men. However, a specification test failed to reject the hypothesis of equality among various indicators of alcohol consumption. Acknowledging the potential bias from unobserved heterogeneity, the authors also estimated a two-stage least squares (2SLS) model. They did not report the results from 2SLS because their instruments performed very poorly. The authors reached this conclusion on the basis of “implausibly" large estimates and high standard errors.

A second body of research assessed the relationship between the labor market productivity and "problem drinking", usually defined as alcoholism or heavy drinking (Benham and Benham, 1982; Mullahy and Sindelar, 1991, 1993, and 1996; Kenkel and Ribar, 1994). A series of papers by Mullahy and Sindelar carefully attempted at identifying the impact of problem drinking on labor market behavior of individuals in the United States. Mullahy and Sindelar (1993) found a significant and negative effect of alcoholism on employment and income for prime-aged males (ages 30 to 59), but not for younger or older individuals. Although, the authors mentioned the potential endogeneity of alcohol consumption, they treated it as an exogenous determinant of labor market activity due to a lack of any reasonable instruments. More importantly, the authors stressed the possibility that unobserved heterogeneity might ultimately be driving all the 
outcomes that were studied. ${ }^{2}$ Mullahy and Sindelar (1996) estimated both OLS and IV models to assess the impact of problem drinking on employment and unemployment using data from the 1988 Alcohol Supplement of the U.S. National Health Interview Survey. Their results were consistent with their earlier findings that problem drinking lowers employment and increases unemployment. Given the insignificance of their IV estimates for both males and females, the authors pointed the importance of additional research with new data sets and improved measures.

Kenkel and Ribar (1994) explored how alcohol abuse and heavy drinking affect earnings, labor supply, and marital status for males and females, using the 1989 panel of the National Longitudinal Survey of Youth. In addition to the OLS, the authors performed an IV estimation to account for unobserved heterogeneity and the possibility that alcohol consumption and earnings may be simultaneously determined. They also used individual fixed effects and data from siblings to further control for unobserved heterogeneity. This study is unique in the sense that it is the only one in the literature to exploit the longitudinal nature of a data set to investigate alcohol consumption-labor market behavior relationship. However, it is worth noting that their measure of heavy drinking is different from the alcohol consumption measure used in this study. Their results suggested that alcohol abuse has small effects on labor supply, negative and significant for males, but positive and insignificant for females. They also reported small and positive, but insignificant impacts on labor supply of both males and females.

In sum, a review of the past literature reveals that studies using alcohol consumption as the measure of drinking usually finds a positive or an inverse U-shaped relationship between drinking and labor market productivity. On the other hand, studies using the clinical diagnosis of alcoholism or heavy drinking as the measure of drinking

\footnotetext{
${ }^{2}$ The same concern is also raised by other researchers (e.g. Hamilton and Hamilton, 1997; MacDonalds and Shields, 2001; Zarkin et al., 1998).
} 
document that problem drinking or alcoholism has deterrent effects on employment and earnings. ${ }^{3}$ The limitation of having to use cross-sectional data has been usually acknowledged as a shortcoming (French and Zarkin, 1995; Hamilton and Hamilton, 1997). ${ }^{4}$ Researchers typically discussed the potential endogeneity of alcohol consumption and several studies attempted to correct for possible bias by employing the IV method. The IV method usually generated larger estimates than OLS. However, the coefficients were mostly estimated with little precision, mainly due to weak identification.

\section{Conceptual Issues and Empirical Strategy}

There are several mechanisms through which alcohol consumption may influence labor market outcomes. One of these mechanisms is grounded on the basis of considerable evidence in the medical literature, which identifies a U-shaped association between alcohol consumption and the risk of cardiovascular heart disease. According to this literature, alcohol consumption at moderate levels may be beneficial for health by relieving stress and reducing the incidence of cardiovascular heart disease. In addition to the medical relationship, another informal mechanism might also drive the positive association between alcohol consumption and labor market outcomes. In particular, alcohol may play a "networking" role if consumed in order to spend time with colleagues at work. The argument is that time spent with colleagues might serve as a signal for the individual's motivation or commitment to the firm or helps him/her derive additional information about the firm's promotion opportunities (MacDonald and Shields, 2001).

\footnotetext{
${ }^{3}$ A number of studies also provided evidence of a positive effect of illicit drug use on earnings (Kaestner, 1991; Gill and Michaels, 1992). Most recently, Dave and Kaestner (2001) find a weak and indeterminate relationship between alcohol taxes and labor market outcomes, which implies that alcohol use does not adversely affect labor market outcomes.
} 
Conversely, studies using the alcoholism or problem drinking as the appropriate measure of alcohol consumption are primarily motivated by the medical evidence linking alcoholism and heavy drinking to a number of physical, psychological, and cognitive impairments, which would be detrimental to individuals' labor market productivity (Farrel, 1985; Fingarette, 1988a, b; Cruze et al., 1991). The common finding of a negative association between problem drinking and labor market outcomes by the studies using problem drinking as the measure of alcohol consumption is grounded on this basis.

The relationship between labor market outcomes and alcohol consumption can be formulated by the following econometric model

$$
\mathrm{Y}_{\mathrm{i}}=\mathbf{X}_{\mathrm{i}} \beta_{1}+\mathbf{A}_{\mathrm{i}} \beta_{2}+\varepsilon_{\mathrm{i}}
$$

where $\mathrm{Y}_{\mathrm{i}}$ is the outcome measure such as employment or the wage rate for individual $\mathrm{i}$. $\mathbf{X}_{\mathrm{i}}$ is a vector of the exogenous variables (demographics, human capital variables, occupational indicators, etc.), and $\mathbf{A}_{\mathrm{i}}$ is a vector of alcohol consumption variables. The $\beta$ 's are the associated parameters and the $\varepsilon_{\mathrm{i}}$ is the disturbance. It is not straightforward to establish a casual relationship between $\mathbf{A}_{\mathrm{i}}$ and $\mathrm{Y}_{\mathrm{i}}$ empirically in equation (1). In particular, if there are unobserved individual factors that are correlated with both drinking and the labor market outcomes, the coefficient $\beta_{2}$ would be biased. For example, individuals with a high rate of time preference may be more likely to make their consumption decisions based on the current satisfaction they derive, without considering the future consequences (Becker and Murphy, 1988). These individuals may also be more likely to select jobs with flatter age/earnings profiles. In this case, the unobserved individual factor, the rate of time preference, may create a spurious correlation between the error term and $\mathbf{A}_{\mathrm{i}}$. As another example, if individuals who drink are more likely to socialize with their colleagues at work, they may also be more likely to have better labor market outcomes in the form of staying employed or commending higher earnings 
(MacDonalds and Shields, 2001). This would cause the $\beta_{2}$ to be biased upwards.

Alternatively, drinking may also serve as a negative signal to employers about the individual's productivity or suitability for promotion, creating a downward bias on the estimate of $\beta_{2}$. Therefore, the estimation of equation (1) by OLS may produce biased estimates of the effect of alcohol consumption.

In a cross-sectional framework, a possible remedy for the problem of unobserved heterogeneity would be to include a rich set of personal attributes in the model, but the estimates will still be biased if the information on some of these personal attributes is not available to the researcher. Another approach would be to use the instrumental variables (IV) method. However, the success of the IV method depends largely on the predictive power of the instruments in the first stage equations. The IV method is complicated further with the difficulty of finding instruments that could appropriately be excluded from equation (1).

The use of longitudinal data provides a more appropriate and complete solution to the problem of unobserved individual heterogeneity. The individual fixed effects that are included in the model control for the individual specific characteristics not captured by $\mathbf{X}$. The formulation of a fixed-effects model can be represented as

$$
\mathrm{Y}_{\mathrm{it}}=\mathbf{X}_{\mathrm{it}} \beta_{1}+\mathbf{A}_{\mathrm{it}} \beta_{2}+\mu_{\mathrm{i}}+\eta_{\mathrm{t}}+v_{\mathrm{it}}, \quad \mathrm{i}=1, \ldots \ldots, \mathrm{N} ; \quad \mathrm{t}=1, \ldots \ldots, \mathrm{T},
$$

where the subscript $t$ indicates that the variable is observed in year $t . \mu_{\mathrm{i}}$ represents the unobserved individual characteristics that are time-invariant. Similarly $\eta_{\mathrm{t}}$ represents the unobserved time effects that are controlled for by time dummies. $v_{\text {it }}$ denotes the residual disturbance that is assumed to be uncorrelated with the $\mathbf{X}^{\prime} \mathrm{s}, \mathbf{A}, \mu_{\mathrm{i}}$ and $\eta_{\mathrm{t}}$. Despite its advantage, the fixed-effects method is not without any shortcomings. First, the effects of time-invariant variables cannot be estimated. Second, it will not eliminate the bias if the unobserved individual heterogeneity varies over time. In this case, the IV method 
employed together with the fixed-effects is a possible remedy. Following the previous

literature, this paper uses variables pertaining to the religious beliefs of individuals and alcohol prices at the community level as identifying instruments. Finally, the fixedeffects may intensify the problem of measurement error.

\section{Data}

The data used in the empirical analyses come from the Russia Longitudinal Monitoring Survey (RLMS). ${ }^{5}$ The RLMS is the first nationally representative householdbased survey conducted in Russia. The survey comprises two phases, each of which was conducted on a different sample. Phase one consists of the first four rounds spanning July 1992 to January 1994. Phase two includes rounds five to nine spanning November 1994 to December $2000 .^{6}$ This paper uses data from the last four rounds of the second phase. $^{7}$ The RLMS is an excellent data source for the purposes of this paper. It contains detailed information on labor force behavior and alcohol consumption of the respondents. The variation in the alcohol consumption variable is larger in the RLMS than usually found in other data sets. ${ }^{8}$ In addition, extensive information on topics such as educational attainment, health, occupation and region of residence is available.

The outcomes examined in this paper are employment and the wage rate. Employment is measured by whether or not the individual is employed as of the interview date. The wage rate is defined as the ratio between the total monthly earnings

\footnotetext{
${ }^{5}$ The RLMS is a collaborative effort of the University of North Carolina at Chapel Hill, the Russian Central Statistical Bureau (Goskomstat), and the All-Russia Center of Preventive Medicine. Detailed information about the survey can be found at http://www.cpc.unc.edu/projects/rlms.

${ }^{6}$ Data are collected for 160 survey sites (communities). These 160 sites are allocated into 38 primary sampling units based largely on geographical factors and level of urbanization. These sampling units are then collapsed into 8 regions (See Table 1 for a list of these regions).

${ }^{7}$ The survey dates for these rounds are October-December 1995 for round six, October-December 1996 for round seven, October 1998-January 1999 for round eight, and September-December 2000 for round nine.

${ }^{8}$ Those who consumed at least once in the last 30 days constitute 0.74 of the male and 0.52 of the female samples in the RLMS as compared to 0.70 and 0.45 in the NLSY.
} 
and total number of hours of work in the last 30 days on the main job. Following Glinskaya and Mroz (2001), total monthly earnings are defined by the sum of salaries, wages, bonuses, grants, benefits, and profits plus the monetary value of the in-kind payments actually received in the last 30 days from the main place of employment. In order to adjust for the effect of inflation, the monthly Consumer Price Index (CPI), calculated by the Russian Statistical Bureau (Goskomstat) and published in Russian Economic Trends is used (1998 base).

The survey asks respondents whether or not they consumed any alcohol during the past 30 days. Those who reported in the affirmative are then asked about the number of times they consumed alcohol during the same period. Possible responses are "every day”, "2-3 times a week", "4-6 times a week", “once a week", "2-3 times", and "once in the past 30 days". Two sets of alcohol consumption measures are constructed using these responses. First, a simple binary indicator is created which takes on the value of one if the respondent reports consuming any alcohol in the past 30 days, and zero otherwise. Second, a set of six binary variables is constructed for each of the six drinking categories. This constitutes the primary measure of alcohol consumption in the paper and should capture any possible non-linear association between alcohol consumption and the outcomes analyzed. In addition to these two discrete measures, a third measure of alcohol consumption is defined as a continuous variable. The respondents are asked about their alcohol consumption during the 30 days prior to the interview, distinguishing beer, vodka, fortified wine, table wine, and homemade liquor. Using this information, a measure of composite ethanol consumption per liter is calculated as a weighted average of ethanol typically found in each type of these drinks. The following algorithm is used to construct the measure of ethanol consumption: total amount of ethanol contained in 
(1) beer is 5 percent; (2) vodka and homemade are 40 percent; (3) fortified wine and table wine 20 percent and 12 percent, respectively. ${ }^{9}$

Answers to the alcohol related questions in the RLMS could be viewed with some skepticism since they are self-reported as it is almost always the case in other national surveys. Several studies have examined the validity of self-reported alcohol consumption and have found that there was fairly high correlation between the validity of self-reported alcohol and drug use data and alternative sources of information (Kandel, 1984; Rouse et al. 1985; Midanik, 1982 and 1989). Furthermore, there is little connotation attached to drinking in Russia, which would also improve the truthfulness of the self-reported data on alcohol consumption in this study.

The demographic variables used in the analysis include linear and quadratic terms of age and experience on the current job, years of education, binary indicators of marital status, health, region of residence, and occupation. Occupations are coded according to the four-digit International Standard Classification of Occupations (ISCO-88). These codes are then collapsed into a single digit title, using the guidelines provided in the survey description. After eliminating the titles representing the army and the agricultural sector, eight occupational titles are created. Table 1 contains the list of the variables used in the analysis along with their definitions.

The sample consists of prime-aged individuals (ages 24-58) who are not employed in the army or the agricultural sector and are not self-employed at the time of the survey. In addition, individuals with missing information on the key variables are excluded from the analysis. The final sample consists of 974 men (41\%) and 1382 women (59\%) who were interviewed in each of the last four rounds of the RLMS. It is

\footnotetext{
${ }^{9}$ A similar algorithm was also used in Mullahy and Sindelar (1996).
} 
well established in the literature that males and females differ substantially in their labor market behavior and alcohol consumption (Ferrence, 1980; Wilsnack et al., 1984; Mullahy and Sindelar, 1991; Wilsnack and Wilsnack, 1992; Lex, 1994; Caetano, 1994). Further, females and males differ in their physical reaction to ethanol (Roman, 1988). Given these reasons and following the previous work, analyses are conducted separately for males and females.

Table 2 presents the descriptive statistics for the full sample and by gender, aggregated over the rounds 6-9. Approximately 74 percent of males and 70 percent of females in the sample are employed. The average wage rate is 9.91 rubles for males and 7.97 rubles for females. In terms of the prevalence of alcohol consumption, 74 percent of males and 52 percent of females reported consuming alcohol in the past 30 days. As can be seen from the six categories of alcohol consumption, drinking intensity is dramatically higher for males than females. For example, those who drink at least once a week make up 38 percent of the male sample and only 11 percent of the female sample. These figures suggest that a great majority of females are infrequent drinkers. A similar pattern is observed for the continuous measure of alcohol consumption. The mean value of monthly ethanol consumption for males is more than twice the size for females, pointing to their overall higher consumption of alcohol.

Table 3 presents the mean values of employment and wages by drinking status and gender subgroups. For both males and females, the wage rate is lower for nondrinkers than drinkers. The wage differential seems to persist even for higher drinking levels. Similarly, employment rate is higher for drinkers than non-drinkers, but the differential somewhat gets smaller as the level of drinking intensity increases. 


\section{Empirical Results}

The results of the empirical analyses are presented in two stages. The results from cross-sectional analyses are presented first to provide a link to the previous studies and a base for evaluating the relative contribution of controlling for unobserved heterogeneity. Then, the results from the fixed-effects models are presented. All models include dummy variables representing different rounds. ${ }^{10}$ These dummies control for the unobserved time-variant determinants of alcohol consumption, which affect all individuals in the same fashion. In both stages, three different versions of alcohol consumption are employed. In the first version, all of six indicators of alcohol consumption are included in the regressions. In the second version, these six indicators are collapsed into a binary use/no use indicator. This implicitly assumes that the relationship between alcohol consumption and employment/wage rate is independent of the level of consumption and can be explained by a simple shift in the mean wage rate or employment probability. In the third version, the continuous measure of alcohol consumption defined by monthly ethanol intake is employed. In order to capture a possible nonlinear relationship, both the linear and quadratic measures of ethanol consumption are included.

\section{Baseline Estimates}

Tables 4 and 5 present the cross-sectional OLS estimates for the employment model for males and females, respectively, using pooled data. In the RLMS, the observations are clustered within primary sampling units, which raise a concern about intra-cluster correlation. To account for heteroscedasticity that would be caused by clustered data, a White/Huber correction is implemented in all estimations.

\section{Employment Model}

\footnotetext{
${ }^{10}$ Round nine is the omitted round in all models.
} 
The coefficient estimates for the demographic and human capital variables behave as one would expect, and remain relatively stable across alternative measures of alcohol consumption for both males and females. Increased levels of healthiness are estimated to increase the likelihood that an individual will be employed. Education is estimated to have a small positive impact, although the coefficient estimate is not significant. Age has the expected quadratic shape. Non-wage income has a statistically significant negative coefficient, indicating that leisure is a normal good. Being married is a significant and positive contributor to employment.

Of interest is the impact of alcohol consumption on employment. Looking at the first column of Table 4, which reports the estimates of the six binary indicators of alcohol consumption, there appears to be an inverse- $U$ shaped relationship between employment probability and alcohol consumption, but only three out of six coefficients are statistically significant at conventional levels. However, an F-test for the joint significance of alcohol coefficients rejected the hypothesis that they are jointly zero. On the other hand, the hypothesis of the equality of all six coefficients could not be rejected. This suggests that the six indicators for alcohol consumption can be collapsed into a simple binary indicator as in the second column of Table 4. Referring to column two, the estimate of the binary indicator of alcohol consumption suggests a positive and significant employment differential of about 4 percent.

The third column of Table 4 displays the results from the specification that uses the continuous measure of alcohol consumption. In order to minimize the influence of skewed data, the natural logarithm of the ethanol consumption is used. However, a pure logarithmic transformation cannot be implemented due to the presence of non-drinkers. To overcome this difficulty, the variable is redefined as $\log ($ ethanol +1$){ }^{11}$ The linear

\footnotetext{
${ }^{11}$ A similar transformation is also implemented by French and Zarkin (1995).
} 
and the quadratic terms are estimated to be positive and negative, respectively, and are both statistically significant. This finding lends support to an inverse-U relationship between alcohol consumption and employment.

The results for females are summarized in Table 5. The estimates in column one largely support the hypothesis of the inverse- $U$ relationship between alcohol consumption and employment, but the peak is reached at a lower consumption level when compared with the point estimates of males. Interestingly, the employment propensity is negative for those females who are in the highest three drinking categories. For example, those who reported drinking everyday are about 44 percent less likely to be employed than nondrinkers. The hypotheses of joint insignificance and equality are strongly rejected by Ftests. The existence of an inverse U-shaped association is also confirmed by the estimates in column three that uses the continuous measure of alcohol consumption. In general, the employment propensities for females are more robust and larger in magnitude than those of males in all three specifications.

\section{Wage Model}

Tables 6 and 7 present the cross-sectional OLS results for the wage models for males and females, respectively. In all specifications, the dependent variable is the natural logarithm of the wage rate. In general, the coefficient estimates for the demographic and human capital variables have the expected signs. Education is estimated to have a positive effect on wages. Being married is associated with an increase in the wage rate. Indicators of health status usually have the right sign, but are not estimated with precision. The occupation and the region of residence are estimated to be significant determinants of the wage rate. ${ }^{12}$

\footnotetext{
${ }^{12}$ The occupation indicators are included in the wage model in order to capture the productivity differences that may be associated with working in different occupations. It can be argued that the effect of schooling on earnings operates in part via occupation. The models that exclude occupation dummies did not change
} 
Referring to the first column in Table 6, five of the six estimated coefficients for alcohol consumption categories are positive, but an inverse-U shaped relationship is not obvious. Further, only one of the six coefficients is statistically significant and an F-test failed to reject the hypothesis that these coefficients are jointly zero. As can be seen in the second column, a simple binary indicator of alcohol consumption is estimated to have a small and positive, but insignificant impact on wages. Unlike the discrete measures, both the linear and the quadratic terms of the continuous measure of alcohol consumption are significant. The estimate of the ethanol consumption is positive for the linear term and negative for the quadratic term, supporting the hypothesis of an inverse Urelationship between alcohol consumption and wages.

Turning to females in Table 7, the estimates of the alcohol consumption variables are much larger than males and are estimated much more precisely. With the exception of one coefficient in the first specification, all the estimates of alcohol consumption are significant in all three specifications. The specification tests for joint significance and equality of the six drinking indicators showed that these indicators are significantly different from zero and each other. Further, the point estimates clearly resemble an inverse U-shaped relationship between alcohol consumption and wages. Strikingly, this pattern is also obtained from the continuous measure of alcohol consumption. As can be seen in column three, both the linear and the quadratic terms are significant with positive and negative signs, respectively, supporting the hypothesis of an inverse U-shaped relationship.

In sum, the OLS results discussed above are broadly in accord with the previous research that finds a positive association between alcohol consumption and labor market outcomes. In particular, the relationship is estimated to have an inverse-U shape in both 
employment and wage models for females. This finding is supported by both the discrete and the continuous measures of alcohol consumption. For males, the continuous measure supports the inverse U-shaped relationship, but the evidence is less clear when the discrete measures are used. Further, the estimated coefficients on alcohol variables are larger in magnitude for females than males in all three specifications. This finding is in contrast with French and Zarkin (1998) and MacDonalds and Shields (2001) who document lower figures for females than males.

\section{Fixed Effects}

To address the possible endogeneity of alcohol consumption, the models are estimated with fixed effects. The coefficients on demographic and human capital covariates usually follow a pattern similar to those from the OLS estimates with larger standard errors, but remain stable across alternative specifications for both males and females. The rise in the standard errors is sensible given the fact that most covariates vary little over the rounds. A test of the hypothesis that the effects of individual fixed effects are jointly zero is rejected at better than one percent level. Coefficients on the region of residence and education cannot be estimated since these variables do not change over the rounds. To economize on space, the results on these covariates are not discussed.

\section{Employment Model}

The results for males that are presented in Table 8 differ sharply from those without fixed-effects reported in Table 4, and reveal a lot about the biases in the crosssectional estimates. In all three specifications, the fixed effect estimates of alcohol consumption are very small and are estimated with much less precision. For all practical purposes, the estimates from all three specifications can be considered as zero. Indeed, a specification test confirmed that the six binary indicators of drinking are jointly zero. 
This finding implies that individual unobserved heterogeneity is positively correlated with alcohol consumption and once it is controlled for, the positive impact of alcohol consumption on employment disappears.

Table 9 presents the fixed-effects estimates for the employment model for females. In all cases, the estimates are much smaller than those of cross-sectional models. The point estimates in column one suggest that the inverse-U shaped relationship no longer exists. Specification tests showed that the coefficients of the six alcohol categories are jointly statistically different from zero, and are equal to each other This suggests that a simple binary indicator of alcohol consumption as presented in column two would appropriately capture the effect of alcohol consumption on employment. According to column two, alcohol consumption is associated with a positive and significant employment differential of about 2 percent. The estimates on the continuous alcohol measure also lend support to a small and positive effect. Consistent with column one, the estimated effect is linear since the quadratic term is not statistically significant. These effects are much smaller than those found in the cross-sectional estimations.

Results discussed above suggest that the estimates without fixed effects capture not only the impact of drinking, but also the positive impact on alcohol consumption of the unobserved individual factors. After accounting for unobserved heterogeneity, the drinking males are no more likely to be employed than non-drinking males. For females, drinkers are still more likely to be employed than non-drinkers, but the effect is no longer inverse U-shaped and much smaller than the estimates from the models without fixedeffects. These findings are consistent across the specifications that use different measures of alcohol consumption. The inverse U-shaped or, more generally, a positive 
relationship between alcohol consumption and employment seems to be driven mostly by the unobserved individual heterogeneity.

\section{Wage Models}

The results from the fixed-effects wage models are displayed in Table 10 for males and Table 11 for females. In contrast with the fixed-effects estimates for the employment model, the estimates for the wage model are larger in magnitude than the cross-sectional estimates that do not include the fixed-effects. In column one of Table 10 , all the indicators of alcohol consumption are statistically significant with the exception of the lowest and the highest drinking categories. The estimates indicate that there is a positive return to earnings of alcohol consumption. However, the U-shaped relationship is not supported, and an F-test did not reject the hypothesis that these coefficients are equal to each other. Therefore, a single indicator of alcohol consumption as presented in column two would be enough to appropriately capture the impact of alcohol consumption on earnings. The point estimate in column two indicates that alcohol consumption increases male wages by about 20 percent. The IV methods employed to account for endogeneity in the previous studies usually produced larger effects than the cross-sectional estimates. The figure reported in this paper is consistent with this finding, but is somewhat larger than those reported in previous studies. Referring to column three, the linear term for the continuous measure of alcohol consumption is significant and positive while the quadratic term is insignificant. This finding is in accord with the results from the discrete measures in the first two columns and supports a positive and linear effect of alcohol consumption on wages.

Unlike males, the point estimates for female wages displayed in Table 11 resembles an inverse-U shaped relationship between alcohol consumption and wages. However, the standard errors are large. Furthermore, specification tests rejected that they 
are jointly zero, but failed to reject that they are equal to each other, supporting a linear association as imposed in column two. According to the point estimate in column two, female drinkers earn about 9.5 percent more than female non-drinkers. The finding of a linear association is also supported by the estimates of continuous measure of alcohol consumption, since only the linear term is significant as reported in column three. This is different from the cross-sectional result that strongly suggests an inverse-U shaped relationship. Finally, the magnitudes of the fixed effects estimates are smaller than those found in cross-sectional models.

\section{Sensitivity Tests and Specification Issues}

Several researchers stressed that controlling for several covariates that might be correlated with alcohol consumption (e.g. health status, education, and marital status) could have large impacts in the estimated coefficients of alcohol consumption on labor market outcomes (Mullahy and Sindelar, 1993; French and Zarkin, 1995; MacDonalds and Shields, 2001). If this is true, then it means that alcohol consumption influences labor market outcomes both directly and indirectly through human capital and family formations. To investigate this issue further, all models are re-estimated with education, health, and marital status variables (and experience in the wage models) excluded from the analyses. This exercise produced little change to the estimates of alcohol consumption coefficients. Therefore, the results produced no evidence for a possible indirect association. A similar finding was obtained in Hamilton and Hamilton (2001).

Another concern is that the results might be sensitive to the way the continuous measure of alcohol consumption is defined. Given that the results from the continuous measures closely follow the pattern of the results from the discrete measures, it is useful to further investigate whether the same results hold when the continuous measure is defined in a different way. To examine this issue, the measure of ethanol consumption is 
re-defined with slightly different weights assigned to each type of alcoholic beverage. The results found to be robust to the way the continuous measure is defined.

The empirical analyses in this study implicitly assume that changes in the alcohol consumption are random. However, the concern of a possible simultaneity between alcohol consumption and labor market outcomes was raised by several studies (Kenkel and Ribar, 1994; MacDonalds and Shields, 2001). To the extent that it can be considered just another consumption good, alcohol consumption would depend on income, which is partly determined by wages. In this case, alcohol consumption and wages are simultaneously determined, and a failure to account for the simultaneity would produce biased estimates. The fixed-effects method used in this paper is an appropriate solution for unobserved heterogeneity that is time-invariant, but it does not help account for simultaneous equation bias and time-variant heterogeneity. In order to deal with potential simultaneity and time-variant heterogeneity, the IV method is used together with the fixed effects. Variables reflecting the religious beliefs of individuals, non-wage income, and prices of various alcoholic beverages in the 160 geographic units provided in the data set are used as identifying instruments. The Russian Consumer Price Index for food and beverages is used to deflate the prices from different years to 1998 December rubles. The price information is missing for many sites in some of the rounds. These missing prices are replaced by the average prices from the rounds in which they are available. Using both these instruments and the fixed-effects, the models are re-estimated with 2-Stage Least Squares (2SLS). The point estimates on alcohol consumption variables from 2SLS are much larger than the estimates from both the cross-sectional and fixed effects models. However, none of the estimates of alcohol consumption are statistically significant by conventional standards. Further, the identifying instruments perform very poorly in the first stage, casting doubt on the validity of the 2SLS results. 
On the grounds of weak identification, little value is given to the estimates from 2SLS and they are not presented in the paper.

A final concern is the possibility of sample selection bias in the wage models. The estimates of the effects of alcohol consumption on wages may be biased because the sample is limited to employed individuals only. If the selection is caused by unobserved permanent factors, then the fixed-effects included in the wage equation will account for such selection and there is no need to correct for selectivity. Nevertheless, a Heckman selection procedure is implemented (Heckman, 1979) in order to ensure that the results are not affected by the selection bias. Specifically, first stage models for the decision to work are estimated for each of the four rounds of data. The inverse Mills ratios are calculated from the estimates of these models are then included as regressors in the fixed effects wage models. For both males and females, the estimate on the inverse Mills ratio was insignificant and the estimates on the alcohol consumption variables remained largely unchanged.

\section{Conclusions}

This paper examines the impact of alcohol consumption on employment and wages in Russia. The results presented here highlight the importance of appropriately controlling for unobserved heterogeneity when estimating the relationship between alcohol consumption and labor market outcomes. Utilizing a longitudinal data set, the empirical strategy employed in this study avoids potential contamination of the results due to unobserved heterogeneity. The models are estimated using alternative measures of alcohol consumption with and without fixed effects in order to identify the extent of bias that would stem from failing to control for unobserved heterogeneity. 
The cross-sectional findings support the view that alcohol consumption is positively associated with employment and wages for females. For males, a positive and inverse U-shaped impact is found for both the employment and the wage models that use the continuous measure. On the other hand, the models that use the discrete measures do not support any non-linear association and suggest a linear and positive impact of alcohol consumption on employment and wages. For females, the results strongly confirm the inverse-U shaped form as documented by many other studies in the literature. Thus, the evidence for an inverse-U shaped relationship is stronger for females. Overall, these findings are consistent with the studies for United States, Canada, and Great Britain that employ consumption measures rather than the measures of problem drinking or alcoholism.

The results of the fixed-effects models are very different from those of crosssectional estimates. For the employment models, the inverse-U relationship observed in the cross-sectional results disappeared for both males and females once the unobserved heterogeneity is controlled for. In fact, the impact of alcohol consumption on employment became zero for males and fell sharply for females. This finding suggests that the positive association found in the cross-sectional estimation is ultimately driven by unobserved individual heterogeneity and alcohol consumption has almost no impact on employment. For the wage models, a more complex picture has emerged. It is found that wages are positively affected by alcohol consumption for both males and females. However, the inverse U-shaped relationship no longer exists once fixed effects are included in the model. In fact, the shape of the association is estimated to be linear for both males and females. A comparison between the fixed effects and cross-sectional estimates indicates that controlling for unobserved heterogeneity strengthens the positive impact of alcohol consumption on wages while the reverse is true for females. 
Interestingly, this conclusion holds using the discrete as well as the continuous measures of alcohol consumption for both males and females. 


\section{References}

Beaglehole, R. and R. Jackson (1992). "Alcohol, Cardiovascular Diseases and All Causes of Mortality: A Review of the Epidemiological Evidence," Drug and Alcohol Review II, 275-290.

Becker, S. Gary, and Kevin M. Murphy (1988). "A Theory of Rational Addiction," Journal of Political Economy 96:675-700.

Benham, L. and A. Benham (1992). "Employment, Earnings, and Psychiatric Diagnosis," Economics Aspects of Health, Fuchs V. (Ed.) University of Chicago Press, Chicago.

Berger C. Mark and J. Paul Leigh (1988). "The Effect of Alcohol Use on Wages," Applied Economics 20:1343-1351.

Bofetta, P. and L. Garfinkel (1990). "Alcohol drinking and mortality among men enrolled in an American Cancer Society Prospective Study," Epidemiology 1:342-348.

Caetano, R. (1994). "Drinking and Alcohol-related Problems among Minority Women," Alcohol Health and Research World 18:233-242.

Coate, D. (1993). "Moderate Drinking and Coronary Heart Disease Mortality: Evidence from NHANES I and the NHANES I follow-up," American Journal of Public Health 83:888-890.

Dave, Dhaval and Robert Kaestner. "Alcohol Taxes and Labor Market Outcomes," forthcoming, Journal of Health Economics.

Doll, R., Peto, R., Hall, E., Wheatley, K., Gray, R. (1994). "Mortality in Relation to Consumption of Alcohol: 13 Years' Observations on Male British Doctors," British Medical Journal 309:911-918.

Ferrence, R. G. (1980). "Sex Differences in the Prevalence of Problem Drinking," Alcohol and Drug Problems in Women: Research Advances in Alcohol and Drug Problems, Kaland, D. N. (Ed.) 5:69-124 Plenum: New York.

Fingarette, Herbert (1988a). "Heavy Drinking,” University of California Press, Berkeley, CA.

Fingarette, Herbert (1988)b. "Alcoholism: The Mythical Disease," The Public Interest 91, $3-22$.

French, Michael and Gary A. Zarkin (1995). "Is Moderate Alcohol Use Related to Wages?: Evidence from Four Worksites,” Journal of Health Economics 14:319-344.

Gill A. M. and Robert J. Michaels (1992). “Does Drug Use Lower Wages?,” Industrial and Labor Relations Review 45:419-434. 
Glinskaya, Elena and Thomas A. Mroz (2001). "The Gender Gap in Wages in Russia from 1992 to 1995." Journal of Population Economics 13:353-386.

Hamilton, Vivian and Barton H. Hamilton (1997). "Alcohol and Earnings: Does Drinking Yield a Wage Premium?," Canadian Journal of Economics 30:135-151.

Heckman, James J. (1979). "Sample Selection Bias as a Specification Error," Econometrica 47:153-161.

Heien, Dale M. (1996). “Do Drinkers Earn Less?,” Southern Economic Journal 63:60-68.

ISCO-88 International Standard Classification of Occupations (1988) International Labor Office, Geneva.

Kaestner, Robert (1991). "The Effect of Illicit Drug Use on the Wages of Young Adults," Journal of Labor Economics 9:381-412.

Kenkel, D. S. and David C. Ribar (1994). "Alcohol Consumption and Young Adults' Socioeconomic Status," Brookings Papers on Economics Activity: Microeconomics 119175.

Lex, B. W. (1994). “Alcohol and Other Drug Abuse among Women,” Alcohol Health and Research World 3:212-219.

Macdonald, Ziggy and Michael A. Shields (2001). "The Impact of Alcohol Consumption on Occupational Attainment in England," Economica 68:427-453.

Marmot, M. and E. Brunner (1991). "Alcohol, and Cardiovascular Disease: The Status of the U Shaped Curve," British Medical Journal 303:565-568.

Midanik, L. T. (1982). "The Validity of Self-reported Alcohol Consumption and Alcohol Problems: A Literature Review," British Journal of Addiction 77:357-382.

Midanik, L. T. (1989). "Perspectives on the Validity of Self-reported Alcohol Use," British Journal of Addiction 84:1419-1423.

Mullahy, J. and Jody L. Sindelar (1991). "Gender Differences in Labor Market Effects of Alcoholism," American Economic Review (Papers and Proceedings) 81:161-165.

Mullahy, J. and Jody L. Sindelar (1993). “Alcoholism, Work, and Income,” Journal of Labor Economics 11:494-520.

Mullahy, J and Jody L. Sindelar (1996). "Employment, Unemployment, and Problem Drinking," Journal of Health Economics 15:409-434.

Rice, D. P., S. Kelman, L. S. Miller, and S. Dunmeyer (1990). "The Economic Costs of Alcohol and Drug Abuse and Mental Illness: 1985," Institute for Health and Aging, University of California, San Diego, CA. 
Roman, P. M. (1988). “Biological Features of Women's Alcohol Use: A Review,” Public Health Reports 103:628-637.

Wilsnack, R. W. and S. C. Wilsnack (1992). "Women, Work, and Alcohol: Failures of Simple Theories," Alcoholism: Clinical and Experimental Research 16:172-179.

Wilsnack, S. C., Wilsnack, R. W., and S. Hiller-Sturmhofel (1994). "How Women Drink: Epidemiology of Women's Drinking and Problem Drinking," Alcohol Health and Research World 18:173-184.

Shaper, A. G. (1990). "Alcohol, the Heart, and Health,” Editorial: American Journal of Public Health 83:799-801.

Zarkin, Gary, Mroz, T., Bray, J. and Michael French (1998). "Alcohol Use and Wages: New Results from the National Household Survey on Drug Abuse," Journal of Health Economics 17:53-68. 


\section{Table 1}

\section{Variable Definitions}

\begin{tabular}{|c|c|}
\hline Wage & : Hourly wage rate in rubles \\
\hline Work & : 1 if employed, 0 otherwise \\
\hline Age & : Age in years \\
\hline Education & : Years of completed schooling \\
\hline Never Married & $: 1$ if never married, 0 otherwise \\
\hline Married & $: 1$ if married, 0 otherwise \\
\hline Divorced & : 1 if divorced, 0 otherwise \\
\hline Widowed $^{\text {a }}$ & : 1 if widowed, 0 otherwise \\
\hline Nonwage Income & $\begin{array}{l}\text { : Total monthly income from all sources net of labor } \\
\text { income }\end{array}$ \\
\hline \multicolumn{2}{|l|}{ Health Status } \\
\hline Health 1 & : 1 if health status reported very good, 0 otherwise \\
\hline Health 2 & : 1 if health status reported good, 0 otherwise \\
\hline Health 3 & $: 1$ if health status reported average, 0 otherwise \\
\hline Health 4 & $: 1$ if health status reported bad, 0 otherwise \\
\hline Health $5^{\text {a }}$ & $: 1$ if health status reported very bad, 0 otherwise \\
\hline \multicolumn{2}{|l|}{ Occupation } \\
\hline Occupation 1 & : 1 if senior official or manager, 0 otherwise \\
\hline Occupation 2 & $: 1$ if professional, 0 otherwise \\
\hline Occupation 3 & : 1 if technician or associate professional, 0 otherwise \\
\hline Occupation 4 & : 1 if clerk, 0 otherwise \\
\hline Occupation 5 & : 1 if service or sales worker, 0 otherwise \\
\hline Occupation 6 & : 1 if craft and related trades, 0 otherwise \\
\hline Occupation 7 & $\begin{array}{l}: 1 \text { if plant and machine operators and assemblers, } 0 \\
\text { otherwise }\end{array}$ \\
\hline Occupation $8^{\mathrm{a}}$ & : 1 if elementary occupations, 0 otherwise \\
\hline \multicolumn{2}{|l|}{ Region } \\
\hline Region 1 & : 1 if resides in Moscow and St. Petersburg, 0 otherwise \\
\hline Region 2 & $: 1$ if resides in northern and northwestern, 0 otherwise \\
\hline Region 3 & $\begin{array}{l}: 1 \text { if resides in Central and Central Black-Earth, } 0 \\
\text { otherwise }\end{array}$ \\
\hline Region 4 & $\begin{array}{l}\text { : } 1 \text { if resides in Volga-Vaytski and Volga Basin, } 0 \\
\text { otherwise }\end{array}$ \\
\hline Region 5 & : 1 if resides in North Caucasian, 0 otherwise \\
\hline Region 6 & : 1 if resides in Ural, 0 otherwise \\
\hline Region 7 & : 1 if resides in Western Siberian, 0 otherwise \\
\hline Region $8^{\text {a }}$ & $\begin{array}{l}: 1 \text { if resides in Eastern Siberian and Far Eastern, } 0 \\
\text { otherwise }\end{array}$ \\
\hline Alcohol & $\begin{array}{l}: 1 \text { if used alcoholic beverages in the last } 30 \text { days, } 0 \\
\text { otherwise }\end{array}$ \\
\hline Ethanol & : Ethanol consumed (in grams) in the last 30 days. \\
\hline Drinks every day & $\begin{array}{l}: 1 \text { if used alcoholic beverages every day in the last } 30 \\
\text { days, } 0 \text { otherwise }\end{array}$ \\
\hline Drinks 4-6 times a week & $\begin{array}{l}: 1 \text { if used alcoholic beverages } 4-6 \text { times a week in the last } \\
30 \text { days, } 0 \text { otherwise }\end{array}$ \\
\hline Drinks 2-3 times a week & $\begin{array}{l}: 1 \text { if used alcoholic beverages } 2-3 \text { times a week in the last } \\
30 \text { days, } 0 \text { otherwise }\end{array}$ \\
\hline
\end{tabular}


Drinks once a week $\quad: 1$ if used alcoholic beverages once a week in the last 30 days, 0 otherwise

Drinks 2-3 times a month $\quad: 1$ if used alcoholic beverages 2-3 times in the last 30 days, otherwise

Drinks once a month $\quad: 1$ if used alcoholic beverages once in the last 30 days, 0 otherwise

${ }^{\mathrm{a}}$ Variables omitted in the empirical analyses. 
Table 2

Descriptive Statistics ${ }^{\text {a }}$

\begin{tabular}{|c|c|c|c|}
\hline Variable & Full Sample & Males & Females \\
\hline \multirow[t]{2}{*}{ Work } & 0.716 & 0.741 & 0.699 \\
\hline & $(0.45)$ & $(0.44)$ & $(0.46)$ \\
\hline \multirow[t]{2}{*}{ Wage } & 8.753 & 9.911 & 7.971 \\
\hline & $(13.23)$ & $(14.56)$ & $(12.18)$ \\
\hline \multirow[t]{2}{*}{ Age } & 40.958 & 40.411 & 41.350 \\
\hline & $(9.43)$ & $(9.37)$ & $(9.45)$ \\
\hline \multirow[t]{2}{*}{ Experience } & 8.080 & 7.074 & 8.818 \\
\hline & $(8.57)$ & $(8.29)$ & $(8.70)$ \\
\hline \multirow[t]{2}{*}{ Education } & 9.407 & 9.366 & 9.436 \\
\hline & $(1.32)$ & $(1.32)$ & $(1.32)$ \\
\hline \multirow[t]{2}{*}{ Never Married } & 0.071 & 0.080 & 0.065 \\
\hline & $(0.27)$ & $(0.27)$ & $(0.25)$ \\
\hline \multirow{2}{*}{ Married } & 0.792 & 0.854 & 0.747 \\
\hline & $(0.41)$ & $(0.35)$ & $(0.43)$ \\
\hline \multirow[t]{2}{*}{ Divorced } & 0.089 & 0.058 & 0.111 \\
\hline & $(0.28)$ & $(0.23)$ & $(0.31)$ \\
\hline \multirow[t]{2}{*}{ Widowed } & 0.049 & 0.009 & 0.077 \\
\hline & $(0.22)$ & $(0.95)$ & $(0.27)$ \\
\hline \multirow[t]{2}{*}{ Nonwage Income } & 246.61 & 268.98 & 230.80 \\
\hline & $(881.56)$ & $(683.62)$ & $(650.52)$ \\
\hline \multicolumn{4}{|l|}{ Health Status } \\
\hline \multirow[t]{2}{*}{ Health 1} & 0.015 & 0.025 & 0.009 \\
\hline & $(0.12)$ & $(0.16)$ & $(0.09)$ \\
\hline \multirow[t]{2}{*}{ Health 2} & 0.273 & 0.365 & 0.207 \\
\hline & $(0.45)$ & $(0.48)$ & $(0.41)$ \\
\hline \multirow[t]{2}{*}{ Health 3} & 0.604 & 0.529 & 0.658 \\
\hline & $(0.49)$ & $(0.50)$ & $(0.47)$ \\
\hline \multirow[t]{2}{*}{ Health 4} & 0.098 & 0.073 & 0.116 \\
\hline & $(0.30)$ & $(0.26)$ & $(0.32)$ \\
\hline \multirow[t]{2}{*}{ Health 5} & 0.009 & 0.008 & 0.010 \\
\hline & $(0.09)$ & $(0.09)$ & $(0.10)$ \\
\hline \multicolumn{4}{|l|}{ Occupation } \\
\hline \multirow[t]{2}{*}{ Occupation 1} & 0.022 & 0.029 & 0.018 \\
\hline & $(0.15)$ & $(0.17)$ & $(0.13)$ \\
\hline \multirow[t]{2}{*}{ Occupation 2} & 0.132 & 0.082 & 0.168 \\
\hline & $(0.34)$ & $(0.27)$ & $(0.37)$ \\
\hline \multirow[t]{2}{*}{ Occupation 3} & 0.119 & 0.048 & 0.170 \\
\hline & $(0.32)$ & $(0.21)$ & $(0.38)$ \\
\hline \multirow[t]{2}{*}{ Occupation 4} & 0.051 & 0.009 & 0.081 \\
\hline & $(0.22)$ & $(0.93)$ & $(0.27)$ \\
\hline \multirow[t]{2}{*}{ Occupation 5} & 0.059 & 0.028 & 0.081 \\
\hline & $(0.23)$ & $(0.16)$ & $(0.27)$ \\
\hline \multirow[t]{2}{*}{ Occupation 6} & 0.103 & 0.204 & 0.031 \\
\hline & $(0.30)$ & $(0.40)$ & $(0.17)$ \\
\hline Occupation 7 & 0.137 & 0.263 & 0.046 \\
\hline & $(0.34)$ & $(0.44)$ & $(0.21)$ \\
\hline Occupation 8 & 0.093 & 0.077 & 0.104 \\
\hline
\end{tabular}




\begin{tabular}{|c|c|c|c|}
\hline & $(0.39)$ & $(0.27)$ & $(0.31)$ \\
\hline \multicolumn{4}{|l|}{ Region } \\
\hline \multirow[t]{2}{*}{ Region 1} & 0.050 & 0.043 & 0.054 \\
\hline & $(0.22)$ & $(0.20)$ & $(0.23)$ \\
\hline \multirow[t]{2}{*}{ Region 2} & 0.073 & 0.068 & 0.076 \\
\hline & $(0.26)$ & $(0.25)$ & $(0.27)$ \\
\hline \multirow[t]{2}{*}{ Region 3} & 0.186 & 0.186 & 0.186 \\
\hline & $(0.39)$ & $(0.39)$ & $(0.39)$ \\
\hline \multirow[t]{2}{*}{ Region 4} & 0.203 & 0.210 & 0.198 \\
\hline & $(0.40)$ & $(0.41)$ & $(0.40)$ \\
\hline \multirow{2}{*}{ Region 5} & 0.144 & 0.145 & 0.144 \\
\hline & $(0.35)$ & $(0.35)$ & $(0.35)$ \\
\hline \multirow{2}{*}{ Region 6} & 0.162 & 0.159 & 0.165 \\
\hline & $(0.37)$ & $(0.37)$ & $(0.37)$ \\
\hline \multirow[t]{2}{*}{ Region 7} & 0.106 & 0.112 & 0.101 \\
\hline & $(0.31)$ & $(0,21)$ & $(0.30)$ \\
\hline \multirow[t]{2}{*}{ Region 8} & 0.076 & 0.076 & 0.076 \\
\hline & $(0.26)$ & $(0.27)$ & $(0.26)$ \\
\hline \multirow[t]{2}{*}{ Alcohol } & 0.611 & 0.740 & 0.518 \\
\hline & $(0.49)$ & $(0.44)$ & $(0.50)$ \\
\hline \multirow[t]{2}{*}{ Drinks every day } & 0.009 & 0.019 & 0.003 \\
\hline & $(0.10)$ & $(0.14)$ & $(0.05)$ \\
\hline \multirow[t]{2}{*}{ Drinks 4-6 times/week } & 0.016 & 0.032 & 0.005 \\
\hline & $(0.13)$ & $(0.18)$ & $(0.07)$ \\
\hline \multirow[t]{2}{*}{ Drinks 2-3 times/week } & 0.073 & 0.136 & 0.027 \\
\hline & $(0.26)$ & $(0.34)$ & $(0.16)$ \\
\hline \multirow[t]{2}{*}{ Drinks once/week } & 0.127 & 0.196 & 0.078 \\
\hline & $(0.33)$ & $(0.40)$ & $(0.27)$ \\
\hline \multirow[t]{2}{*}{ Drinks 2-3 times/month } & 0.216 & 0.241 & 0.197 \\
\hline & $(0.411)$ & $(0.43)$ & $(0.40)$ \\
\hline \multirow[t]{2}{*}{ Drinks once/month } & 0.169 & 0.115 & 0.207 \\
\hline & $(0.375)$ & $(0.32)$ & $(0.41)$ \\
\hline \multirow[t]{2}{*}{ Ethanol } & 130.417 & 184.130 & 74.933 \\
\hline & $(144.131)$ & $(166.92)$ & $(86.01)$ \\
\hline Number of Observations & 9,424 & 3,896 & 5,528 \\
\hline
\end{tabular}

\footnotetext{
${ }^{\mathrm{a}}$ Standard errors are in parentheses.
} 
Table 3

Distribution of Employment and Wages ${ }^{\text {a }}$

\begin{tabular}{llcccccc}
\hline & & \multicolumn{2}{c}{ Full Sample } & \multicolumn{2}{c}{ Males } & \multicolumn{2}{c}{ Females } \\
& & Work & Wage & Work & Wage & Work & Wage \\
\hline \multirow{2}{*}{$\begin{array}{l}\text { Drink in } \\
\text { the last } 30\end{array}$} & Yes & 0.755 & 9.557 & 0.758 & 10.285 & 0.752 & 8.909 \\
days & & $(0.43)$ & $(14.83)$ & $(0.43)$ & $(15.69)$ & $(0.43)$ & $(13.99)$ \\
\cline { 2 - 8 } & No & 0.655 & 7.105 & 0.693 & 8.547 & 0.641 & 6.586 \\
& & $(0.48)$ & $(8.97)$ & $(0.46)$ & $(9.37)$ & $(0.48)$ & $(8.77)$ \\
\hline \multirow{5}{*}{$\begin{array}{c}\text { Frequency } \\
\text { of }\end{array}$} & Every & 0.611 & 11.939 & 0.662 & 11.587 & 0.308 & 9.519 \\
drinking & Day & $(0.49)$ & $(14.32)$ & $(0.48)$ & $(13.74)$ & $(0.48)$ & $(14.24)$ \\
\cline { 2 - 8 } & 4-6 times & 0.735 & 13.683 & 0.767 & 13.957 & 0.577 & 11.729 \\
& a week & $(0.44)$ & $(19.58)$ & $(0.42)$ & $(20.70)$ & $(0.50)$ & $(8.14)$ \\
\cline { 2 - 8 } & 2-3 times & 0.720 & 9.866 & 0.736 & 9.515 & 0.665 & 11.001 \\
& a week & $(0.45)$ & $(13.94)$ & $(0.44)$ & $(14.62)$ & $(0.47)$ & $(11.49)$ \\
\cline { 2 - 8 } & Once a & 0.774 & 10.070 & 0.783 & 10.370 & 0.757 & 9.588 \\
& week & $(0.42)$ & $(13.29)$ & $(0.41)$ & $(13.31)$ & $(0.43)$ & $(13.29)$ \\
\cline { 2 - 8 } & 2-3 times & 0.768 & 9.647 & 0.769 & 10.734 & 0.768 & 8.834 \\
& a month & $(0.42)$ & $(17.23)$ & $(0.42)$ & $(13.49)$ & $(0.42)$ & $(15.29)$ \\
\cline { 2 - 8 } & Once a & 0.754 & 8.149 & 0.743 & 8.459 & 0.758 & 8.405 \\
& month & $(0.43)$ & $(12.17)$ & $(0.44)$ & $(8.16)$ & $(0.43)$ & $(13.242)$ \\
\hline
\end{tabular}

${ }^{\mathrm{a}}$ Standard errors are in parentheses. 
Table 4

Cross-sectional Estimates of Employment Equation for Males ${ }^{\text {a }}$

\begin{tabular}{|c|c|c|c|}
\hline Variable & Model One & Model Two & Model Three \\
\hline \multirow[t]{2}{*}{ Constant } & 0.002 & 0.019 & 0.001 \\
\hline & $(0.171)$ & $(0.171)$ & $(0.171)$ \\
\hline \multirow[t]{2}{*}{ Age } & 0.014 & 0.120 & 0.0136 \\
\hline & $(0.006)$ & $(0.006)$ & $(0.006)$ \\
\hline \multirow[t]{2}{*}{$\operatorname{Age}^{2} / 100$} & -0.020 & -0.019 & -0.021 \\
\hline & $(0.008)$ & $(0.008)$ & $(0.009)$ \\
\hline \multirow{2}{*}{ Education } & 0.006 & 0.007 & 0.006 \\
\hline & $(0.005)$ & $(0.005)$ & $(0.005)$ \\
\hline \multirow[t]{2}{*}{ Never Married } & -0.053 & -0.051 & -0.064 \\
\hline & $(0.087)$ & $(0.087)$ & $(0.087)$ \\
\hline \multirow[t]{2}{*}{ Married } & 0.164 & 0.168 & 0.154 \\
\hline & $(0.082)$ & $(0.082)$ & $(0.083)$ \\
\hline \multirow[t]{2}{*}{ Divorced } & -0.045 & -0.039 & -0.046 \\
\hline & $(0.088)$ & $(0.088)$ & $(0.088)$ \\
\hline \multirow[t]{2}{*}{ Health 1} & 0.478 & 0.485 & 0.497 \\
\hline & $(0.085)$ & $(0.085)$ & $(0.083)$ \\
\hline \multirow[t]{2}{*}{ Health 2} & 0.471 & 0.480 & 0.0486 \\
\hline & $(0.072)$ & $(0.072)$ & $(0.071)$ \\
\hline \multirow[t]{2}{*}{ Health 3} & 0.465 & 0.473 & 0.480 \\
\hline & $(0.072)$ & $(0.071)$ & $(0.070)$ \\
\hline \multirow[t]{2}{*}{ Health 4} & 0.194 & 0.196 & 0.197 \\
\hline & $(0.076)$ & $(0.075)$ & $(0.074)$ \\
\hline \multirow[t]{2}{*}{ Nonwage/1000 } & -0.055 & -0.054 & -0.054 \\
\hline & $(0.012)$ & $(0.013)$ & $(0.013)$ \\
\hline \multirow{2}{*}{ Region 1} & -0.065 & -0.068 & -0.075 \\
\hline & $(0.039)$ & $(0.038)$ & $(0.039)$ \\
\hline \multirow[t]{2}{*}{ Region 2} & -0.068 & -0.068 & -0.066 \\
\hline & $(0.033)$ & $(0.032)$ & $(0.032)$ \\
\hline \multirow[t]{2}{*}{ Region 3} & -0.088 & -0.091 & -0.094 \\
\hline & $(0.026)$ & $(0.026)$ & $(0.026)$ \\
\hline \multirow[t]{2}{*}{ Region 4} & -0.096 & -0.102 & -0.104 \\
\hline & $(0.025)$ & $(0.025)$ & $(0.025)$ \\
\hline \multirow[t]{2}{*}{ Region 5} & -0.219 & -0.223 & -0.223 \\
\hline & $(0.029)$ & $(0.029)$ & $(0.029)$ \\
\hline \multirow[t]{2}{*}{ Region 6} & -0.118 & -0.116 & -0.116 \\
\hline & $(0.026)$ & $(0.026)$ & $(0.026)$ \\
\hline \multirow[t]{2}{*}{ Region 7} & -0.063 & -0.063 & -0.061 \\
\hline & $(0.028)$ & $(0.028)$ & $(0.028)$ \\
\hline \multirow[t]{2}{*}{ Dummy Round6 } & 0.033 & 0.032 & 0.032 \\
\hline & $(0.019)$ & $(0.019)$ & $(0.019)$ \\
\hline \multirow{2}{*}{ Dummy ${ }_{\text {Round7 }}$} & 0.000 & -0.001 & 0.000 \\
\hline & $(0.019)$ & $(0.019)$ & $(0.019)$ \\
\hline \multirow[t]{2}{*}{ Dummy ${ }_{\text {Round8 }}$} & -0.025 & -0.027 & -0.027 \\
\hline & $(0.019)$ & $(0.019)$ & $(0.019)$ \\
\hline Alcohol & --- & 0.038 & --- \\
\hline
\end{tabular}




\begin{tabular}{|c|c|c|c|}
\hline & & $(0.016)$ & \\
\hline Drinks every day & $\begin{array}{l}-0.034 \\
(0.053)\end{array}$ & --- & --- \\
\hline Drinks 4-6 times/week & $\begin{array}{c}0.052 \\
(0.024)\end{array}$ & --- & --- \\
\hline Drinks 2-3 times/week & $\begin{array}{c}0.065 \\
(0.048)\end{array}$ & --- & --- \\
\hline Drinks once/week & $\begin{array}{c}0.056 \\
(0.020)\end{array}$ & --- & --- \\
\hline Drinks 2-3 times/month & $\begin{array}{c}0.049 \\
(0.019)\end{array}$ & --- & --- \\
\hline Drinks once/month & $\begin{array}{c}0.017 \\
(0.023)\end{array}$ & --- & --- \\
\hline Ln(Ethanol) & --- & --- & $\begin{array}{c}0.058 \\
(0.012)\end{array}$ \\
\hline $\operatorname{Ln}(\text { Ethanol })^{2}$ & --- & --- & $\begin{array}{l}-0.010 \\
(0.002)\end{array}$ \\
\hline Number of Observations & 3,896 & 3,896 & 3,896 \\
\hline 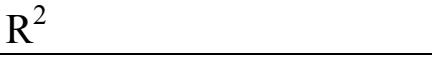 & 0.117 & 0.116 & 0.120 \\
\hline
\end{tabular}

${ }^{\mathrm{a}}$ Standard errors are in parentheses. 
Table 5

Cross-sectional Estimates of Employment Equation for Females a

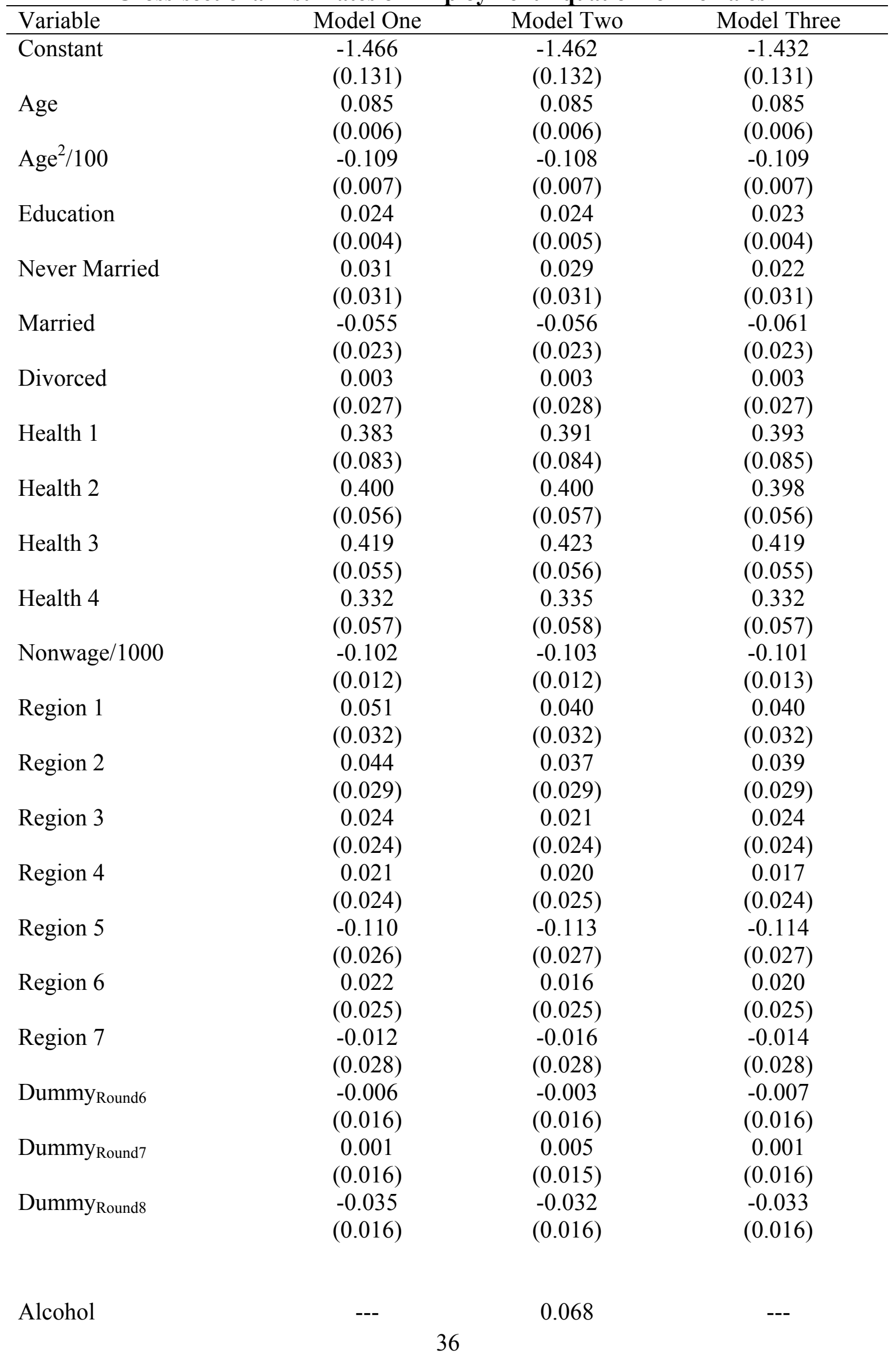




\begin{tabular}{|c|c|c|c|}
\hline & & $(0.012)$ & \\
\hline Drinks every day & $\begin{array}{l}-0.439 \\
(0.119)\end{array}$ & --- & --- \\
\hline Drinks 4-6 times/week & $\begin{array}{l}-0.166 \\
(0.099)\end{array}$ & --- & --- \\
\hline Drinks 2-3 times/week & $\begin{array}{l}-0.025 \\
(0.040)\end{array}$ & --- & --- \\
\hline Drinks once/week & $\begin{array}{c}0.064 \\
(0.022)\end{array}$ & --- & --- \\
\hline Drinks 2-3 times/month & $\begin{array}{c}0.078 \\
(0.015)\end{array}$ & --- & --- \\
\hline Drinks once/month & $\begin{array}{c}0.022 \\
(0.011)\end{array}$ & --- & --- \\
\hline Ln(Ethanol) & --- & --- & $\begin{array}{c}0.092 \\
(0.011)\end{array}$ \\
\hline $\operatorname{Ln}(\text { Ethanol })^{2}$ & --- & --- & $\begin{array}{c}-0.019 \\
(0.003)\end{array}$ \\
\hline $\begin{array}{l}\text { Number of Observations } \\
\mathrm{R}^{2}\end{array}$ & $\begin{array}{l}5,528 \\
0.147\end{array}$ & $\begin{array}{l}5,528 \\
0.142\end{array}$ & $\begin{array}{l}5,528 \\
0.148\end{array}$ \\
\hline
\end{tabular}

${ }^{\mathrm{a}}$ Standard errors are in parentheses. 
Table 6 Cross-sectional Estimates of $\log \left(\right.$ Wage) Equation for Males ${ }^{\text {a }}$

\begin{tabular}{|c|c|c|c|}
\hline Variable & Model One & Model Two & Model Three \\
\hline \multirow{2}{*}{ Constant } & 0.297 & 0.313 & 0.301 \\
\hline & $(0.526)$ & $(0.518)$ & $(0.525)$ \\
\hline \multirow[t]{2}{*}{ Age } & 0.028 & 0.027 & 0.031 \\
\hline & $(0.023)$ & $(0.023)$ & $(0.023)$ \\
\hline \multirow[t]{2}{*}{$\operatorname{Age}^{2} / 100$} & -0.041 & -0.040 & -0.045 \\
\hline & (0.028) & $(0.028)$ & $(0.028)$ \\
\hline \multirow[t]{2}{*}{ Experience } & 0.006 & 0.000 & 0.005 \\
\hline & (0.009) & (0.009) & (0.009) \\
\hline \multirow{2}{*}{ Experience $^{2} / 100$} & -0.018 & -0.019 & -0.017 \\
\hline & $(0.031)$ & $(0.031)$ & $(0.031)$ \\
\hline \multirow[t]{2}{*}{ Education } & 0.058 & 0.056 & 0.056 \\
\hline & $(0.020)$ & $(0.020)$ & $(0.020)$ \\
\hline \multirow{2}{*}{ Never Married } & 0.293 & 0.289 & 0.279 \\
\hline & $(0.279)$ & $(0.270)$ & $(0.280)$ \\
\hline \multirow[t]{2}{*}{ Married } & 0.546 & 0.545 & 0.538 \\
\hline & $(0.256)$ & $(0.248)$ & $(0.258)$ \\
\hline \multirow{2}{*}{ Divorced } & 0.093 & 0.089 & 0.094 \\
\hline & $(0.277)$ & $(0.269)$ & $(0.280)$ \\
\hline \multirow[t]{2}{*}{ Health 1} & 0.298 & 0.284 & 0.299 \\
\hline & $(0.225)$ & $(0.224)$ & $(0.223)$ \\
\hline \multirow{2}{*}{ Health 2} & 0.284 & 0.271 & 0.283 \\
\hline & $(0.139)$ & $(0.137)$ & $(0.137)$ \\
\hline \multirow[t]{2}{*}{ Health 3} & -0.334 & -0.322 & -0.335 \\
\hline & $(0.133)$ & $(0.132)$ & $(0.131)$ \\
\hline \multirow[t]{2}{*}{ Health 4} & -0.282 & -0.273 & -0.292 \\
\hline & $(0.166)$ & (0.164) & $(0.165)$ \\
\hline \multirow[t]{2}{*}{ Region 1} & 0.765 & 0.782 & 0.762 \\
\hline & $(0.124)$ & $(0.122)$ & $(0.122)$ \\
\hline \multirow[t]{2}{*}{ Region 2} & 0.531 & 0.533 & 0.533 \\
\hline & $(0.130)$ & $(0.130)$ & $(0.129)$ \\
\hline \multirow[t]{2}{*}{ Region 3} & 0.178 & 0.183 & 0.168 \\
\hline & (0.108) & $(0.108)$ & $(0.107)$ \\
\hline \multirow[t]{2}{*}{ Region 4} & -0.033 & -0.022 & -0.037 \\
\hline & $(0.107)$ & $(0.107)$ & $(0.106)$ \\
\hline \multirow[t]{2}{*}{ Region 5} & -0.016 & -0.005 & -0.013 \\
\hline & (0.117) & $(0.117)$ & $(0.116)$ \\
\hline \multirow[t]{2}{*}{ Region 6} & 0.266 & 0.270 & 0.266 \\
\hline & $(0.110)$ & $(0.109)$ & $(0.108)$ \\
\hline \multirow[t]{2}{*}{ Region 7} & 0.086 & 0.093 & 0.086 \\
\hline & $(0.134)$ & $(0.133)$ & $(0.133)$ \\
\hline \multirow[t]{2}{*}{ Occupation 1} & 0.660 & 0.667 & 0.653 \\
\hline & $(0.120)$ & $(0.120)$ & $(0.120)$ \\
\hline \multirow{2}{*}{ Occupation 2} & 0.331 & 0.334 & 0.321 \\
\hline & $(0.078)$ & $(0.078)$ & $(0.078)$ \\
\hline \multirow[t]{2}{*}{ Occupation 3} & 0.550 & 0.554 & 0.547 \\
\hline & $(0.092)$ & $(0.092)$ & $(0.093)$ \\
\hline Occupation 4 & -0.195 & -0.229 & -0.232 \\
\hline
\end{tabular}




\begin{tabular}{|c|c|c|c|}
\hline & $(0.194)$ & $(0.189)$ & $(0.193)$ \\
\hline \multirow[t]{2}{*}{ Occupation 5} & 0.108 & 0.121 & 0.117 \\
\hline & $(0.117)$ & $(0.118)$ & $(0.118)$ \\
\hline \multirow[t]{2}{*}{ Occupation 6} & 0.192 & 0.195 & 0.194 \\
\hline & $(0.057)$ & $(0.056)$ & $(0.056)$ \\
\hline \multirow[t]{2}{*}{ Dummy ${ }_{\text {Round6 }}$} & -0.021 & -0.026 & -0.032 \\
\hline & $(0.065)$ & $(0.065)$ & $(0.065)$ \\
\hline \multirow[t]{2}{*}{ Dummy Round7 } & 0.092 & 0.094 & 0.088 \\
\hline & $(0.069)$ & $(0.069)$ & $(0.069)$ \\
\hline \multirow[t]{2}{*}{ Dummy Round8 } & -0.291 & -0.293 & -0.295 \\
\hline & $(0.063)$ & $(0.063)$ & $(0.063)$ \\
\hline \multirow[t]{2}{*}{ Alcohol } & --- & 0.043 & --- \\
\hline & & $(0.055)$ & \\
\hline \multirow[t]{2}{*}{ Drinks every day } & -0.014 & --- & --- \\
\hline & $(0.181)$ & & \\
\hline \multirow[t]{2}{*}{ Drinks 4-6 times/week } & 0.225 & --- & --- \\
\hline & $(0.130)$ & & \\
\hline \multirow[t]{2}{*}{ Drinks 2-3 times/week } & 0.072 & --- & --- \\
\hline & $(0.081)$ & & \\
\hline \multirow[t]{2}{*}{ Drinks once/week } & 0.066 & --- & --- \\
\hline & $(0.070)$ & & \\
\hline \multirow[t]{2}{*}{ Drinks 2-3 times/month } & 0.040 & --- & --- \\
\hline & $(0.068)$ & & \\
\hline \multirow[t]{2}{*}{ Drinks once/month } & 0.006 & --- & --- \\
\hline & $(0.80)$ & & \\
\hline \multirow[t]{2}{*}{ Ln(Ethanol) } & --- & --- & 0.088 \\
\hline & & & $(0.044)$ \\
\hline \multirow[t]{2}{*}{$\operatorname{Ln}(\text { Ethanol })^{2}$} & --- & --- & -0.016 \\
\hline & & & $(0.008)$ \\
\hline Number of Observations & 1,894 & 1,894 & 1,894 \\
\hline $\mathrm{R}^{2}$ & 0.122 & 0.121 & 0.122 \\
\hline
\end{tabular}




\section{Table 7}

\section{Cross-sectional Estimates Log(Wage) Equation for Females ${ }^{\text {a }}$}

\begin{tabular}{|c|c|c|c|}
\hline Variable & Model One & Model Two & Model Three \\
\hline \multirow[t]{2}{*}{ Constant } & 0.832 & 0.904 & 0.920 \\
\hline & $(0.475)$ & $(0.475)$ & $(0.476)$ \\
\hline \multirow[t]{2}{*}{ Age } & 0.016 & 0.012 & 0.012 \\
\hline & $(0.018)$ & $(0.018)$ & $(0.018)$ \\
\hline \multirow[t]{2}{*}{$\mathrm{Age}^{2} / 100$} & -0.018 & -0.013 & -0.014 \\
\hline & $(0.022)$ & $(0.022)$ & $(0.022)$ \\
\hline \multirow[t]{2}{*}{ Experience } & -0.006 & -0.005 & -0.006 \\
\hline & $(0.006)$ & $(0.006)$ & $(0.006)$ \\
\hline \multirow[t]{2}{*}{ Experience $^{2} / 100$} & 0.024 & 0.022 & 0.021 \\
\hline & $(0.022)$ & $(0.022)$ & $(0.022)$ \\
\hline \multirow[t]{2}{*}{ Education } & 0.028 & 0.029 & 0.029 \\
\hline & $(0.018)$ & $(0.017)$ & $(0.018)$ \\
\hline \multirow{2}{*}{ Never Married } & 0.072 & 0.073 & 0.075 \\
\hline & $(0.093)$ & $(0.093)$ & $(0.093)$ \\
\hline \multirow[t]{2}{*}{ Married } & 0.086 & 0.086 & 0.087 \\
\hline & $(0.071)$ & $(0.070)$ & $(0.070)$ \\
\hline \multirow[t]{2}{*}{ Divorced } & 0.079 & 0.090 & 0.094 \\
\hline & $(0.086)$ & $(0.085)$ & $(0.085)$ \\
\hline \multirow{2}{*}{ Health 1} & 0.275 & 0.281 & 0.279 \\
\hline & $(0.328)$ & $(0.325)$ & $(0.322)$ \\
\hline \multirow[t]{2}{*}{ Health 2} & 0.189 & 0.189 & 0.193 \\
\hline & $(0.270)$ & $(0.267)$ & $(0.265)$ \\
\hline \multirow[t]{2}{*}{ Health 3} & -0.154 & -0.149 & -0.153 \\
\hline & $(0.268)$ & $(0.265)$ & $(0.263)$ \\
\hline \multirow{2}{*}{ Health 4} & -0.424 & -0.418 & -0.425 \\
\hline & $(0.273)$ & $(0.270)$ & $(0.268)$ \\
\hline \multirow[t]{2}{*}{ Region 1} & 0.612 & 0.640 & 0.651 \\
\hline & (0.099) & $(0.097)$ & $(0.097)$ \\
\hline \multirow[t]{2}{*}{ Region 2} & 0.209 & 0.220 & 0.223 \\
\hline & $(0.098)$ & $(0.097)$ & $(0.098)$ \\
\hline \multirow{2}{*}{ Region 3} & -0.048 & -0.043 & -0.045 \\
\hline & $(0.083)$ & $(0.083)$ & $(0.083)$ \\
\hline \multirow[t]{2}{*}{ Region 4} & -0.297 & -0.296 & -0.296 \\
\hline & $(0.082)$ & $(0.082)$ & $(0.082)$ \\
\hline \multirow[t]{2}{*}{ Region 5} & -0.368 & -0.361 & -0.361 \\
\hline & $(0.088)$ & $(0.088)$ & $(0.088)$ \\
\hline \multirow[t]{2}{*}{ Region 6} & -0.077 & -0.069 & -0.070 \\
\hline & $(0.083)$ & $(0.083)$ & $(0.083)$ \\
\hline \multirow[t]{2}{*}{ Region 7} & 0.178 & 0.177 & 0.176 \\
\hline & $(0.101)$ & $(0.102)$ & $(0.102)$ \\
\hline \multirow[t]{2}{*}{ Occupation 1} & 0.445 & 0.463 & 0.467 \\
\hline & $(0.115)$ & $(0.115)$ & $(0.115)$ \\
\hline \multirow[t]{2}{*}{ Occupation 2} & 0.450 & 0.450 & 0.452 \\
\hline & $(0.056)$ & $(0.056)$ & $(0.056)$ \\
\hline \multirow[t]{2}{*}{ Occupation 3} & 0.207 & 0.211 & 0.208 \\
\hline & $(0.058)$ & $(0.058)$ & $(0.058)$ \\
\hline Occupation 4 & 0.235 & 0.240 & 0.240 \\
\hline
\end{tabular}




\begin{tabular}{|c|c|c|c|}
\hline & $(0.064)$ & $(0.064)$ & $(0.064)$ \\
\hline \multirow[t]{2}{*}{ Occupation 5} & 0.097 & 0.110 & 0.109 \\
\hline & $(0.066)$ & $(0.065)$ & $(0.065)$ \\
\hline \multirow[t]{2}{*}{ Occupation 6} & 0.232 & 0.228 & 0.225 \\
\hline & $(0.084)$ & $(0.085)$ & $(0.085)$ \\
\hline \multirow[t]{2}{*}{ Dummy ${ }_{\text {Round6 }}$} & 0.115 & 0.112 & 0.114 \\
\hline & $(0.047)$ & $(0.047)$ & $(0.047)$ \\
\hline \multirow[t]{2}{*}{ Dummy ${ }_{\text {Round7 }}$} & 0.151 & 0.147 & 0.148 \\
\hline & $(0.049)$ & $(0.049)$ & $(0.049)$ \\
\hline \multirow[t]{2}{*}{ Dummy } & -0.185 & -0.188 & -0.187 \\
\hline & $(0.046)$ & $(0.047)$ & $(0.047)$ \\
\hline \multirow[t]{2}{*}{ Alcohol } & --- & 0.143 & \\
\hline & & $(0.036)$ & \\
\hline \multirow[t]{2}{*}{ Drinks every day } & -0.467 & -- & --- \\
\hline & $(1.108)$ & & \\
\hline \multirow[t]{2}{*}{ Drinks 4-6 times/week } & 0.315 & --- & --- \\
\hline & $(0.282)$ & & \\
\hline \multirow[t]{2}{*}{ Drinks 2-3 times/week } & 0.409 & --- & --- \\
\hline & $(0.107)$ & & \\
\hline \multirow{2}{*}{ Drinks once/week } & 0.214 & --- & --- \\
\hline & $(0.063)$ & & \\
\hline \multirow[t]{2}{*}{ Drinks 2-3 times/month } & 0.114 & --- & --- \\
\hline & $(0.046)$ & & \\
\hline \multirow[t]{2}{*}{ Drinks once/month } & 0.097 & --- & --- \\
\hline & $(0.045)$ & & \\
\hline \multirow[t]{2}{*}{ Ln(Ethanol) } & --- & --- & 0.071 \\
\hline & & & $(0.036)$ \\
\hline \multirow{2}{*}{$\operatorname{Ln}(\text { Ethanol })^{2}$} & --- & --- & -0.010 \\
\hline & & & $(0.006)$ \\
\hline Number of Observations & 2,831 & 2,831 & 2,831 \\
\hline $\mathrm{R}^{2}$ & 0.141 & 0.138 & 0.136 \\
\hline
\end{tabular}


Table 8

Fixed-effects Estimates of Employment Equation for Males ${ }^{\text {a }}$

\begin{tabular}{|c|c|c|c|}
\hline Variable & Model One & Model Two & Model Three \\
\hline \multirow[t]{2}{*}{ Constant } & -0.579 & -0.656 & -0.675 \\
\hline & $(1.005)$ & (1.001) & $(1.003)$ \\
\hline \multirow[t]{2}{*}{ Never Married } & 0.008 & 0.025 & 0.023 \\
\hline & $(0.117)$ & $(0.116)$ & $(0.117)$ \\
\hline \multirow[t]{2}{*}{ Married } & 0.021 & 0.038 & 0.037 \\
\hline & $(0.104)$ & $(0.103)$ & $(0.104)$ \\
\hline \multirow[t]{2}{*}{ Divorced } & -0.018 & -0.001 & -0.002 \\
\hline & $(0.109)$ & $(0.108)$ & $(0.108)$ \\
\hline \multirow[t]{2}{*}{ Health 1} & 0.145 & 0.158 & 0.160 \\
\hline & $(0.086)$ & $(0.086)$ & $(0.086)$ \\
\hline \multirow[t]{2}{*}{ Health 2} & 0.080 & 0.094 & 0.095 \\
\hline & $(0.075)$ & $(0.076)$ & $(0.076)$ \\
\hline \multirow{2}{*}{ Health 3} & 0.074 & 0.087 & 0.087 \\
\hline & $(0.074)$ & $(0.074)$ & $(0.075)$ \\
\hline \multirow[t]{2}{*}{ Health 4} & 0.052 & 0.057 & 0.058 \\
\hline & $(0.073)$ & $(0.073)$ & $(0.074)$ \\
\hline \multirow[t]{2}{*}{ Nonwage/1000 } & -0.035 & -0.034 & -0.035 \\
\hline & $(0.001)$ & $(0.001)$ & $(0.001)$ \\
\hline \multirow[t]{2}{*}{ Dummy $_{\text {Round6 }}$} & 0.139 & 0.145 & 0.149 \\
\hline & $(0.111)$ & $(0.111)$ & $(0.111)$ \\
\hline \multirow[t]{2}{*}{ Dummy Round7 } & 0.077 & 0.081 & 0.085 \\
\hline & $(0.090)$ & $(0.089)$ & $(0.089)$ \\
\hline \multirow[t]{2}{*}{ Dummy ${ }_{\text {Round8 }}$} & 0.017 & -0.018 & 0.020 \\
\hline & $(0.045)$ & $(0.019)$ & $(0.046)$ \\
\hline Alcohol & --- & $\begin{array}{c}-0.004 \\
(0.017)\end{array}$ & --- \\
\hline Drinks every day & $\begin{array}{l}-0.097 \\
(0.048)\end{array}$ & --- & --- \\
\hline Drinks 4-6 times/week & $\begin{array}{c}0.040 \\
(0.039)\end{array}$ & --- & --- \\
\hline Drinks 2-3 times/week & $\begin{array}{c}0.002 \\
(0.024)\end{array}$ & --- & --- \\
\hline Drinks once/week & $\begin{array}{c}0.005 \\
(0.021)\end{array}$ & --- & --- \\
\hline Drinks 2-3 times/month & $\begin{array}{c}0.007 \\
(0.019)\end{array}$ & --- & --- \\
\hline Once/month & $\begin{array}{l}-0.016 \\
(0.023)\end{array}$ & --- & --- \\
\hline Ln(Ethanol) & --- & --- & $\begin{array}{c}0.008 \\
(0.006)\end{array}$ \\
\hline $\operatorname{Ln}(\text { Ethanol })^{2}$ & --- & --- & $\begin{array}{l}-0.002 \\
(0.002)\end{array}$ \\
\hline Number of Observations & 3896 & 3896 & 3896 \\
\hline $\mathrm{R}^{2}$ & 0.701 & 0.697 & 0.696 \\
\hline
\end{tabular}


Table 9

Fixed-effects Estimates of Employment Equation for Females ${ }^{\text {a }}$

\begin{tabular}{|c|c|c|c|}
\hline Variable & Model One & Model Two & Model Three \\
\hline \multirow[t]{2}{*}{ Constant } & -2.644 & -2.694 & -2.686 \\
\hline & $(0.696)$ & $(0.694)$ & $(0.693)$ \\
\hline \multirow[t]{2}{*}{ Never Married } & -0.066 & -0.070 & -0.071 \\
\hline & $(0.053)$ & $(0.053)$ & $(0.053)$ \\
\hline \multirow[t]{2}{*}{ Married } & -0.113 & -0.114 & -0.114 \\
\hline & $(0.033)$ & $(0.033)$ & $(0.033)$ \\
\hline \multirow[t]{2}{*}{ Divorced } & -0.070 & -0.072 & -0.072 \\
\hline & $(0.039)$ & $(0.039)$ & $(0.039)$ \\
\hline \multirow[t]{2}{*}{ Health 1} & 0.135 & 0.135 & 0.132 \\
\hline & $(0.085)$ & $(0.085)$ & $(0.085)$ \\
\hline \multirow{2}{*}{ Health 2} & 0.113 & 0.111 & 0.110 \\
\hline & $(0.056)$ & $(0.055)$ & $(0.055)$ \\
\hline \multirow[t]{2}{*}{ Health 3} & 0.106 & 0.106 & 0.104 \\
\hline & $(0.054)$ & $(0.054)$ & $(0.054)$ \\
\hline \multirow[t]{2}{*}{ Health 4} & 0.089 & 0.087 & 0.086 \\
\hline & $(0.054)$ & $(0.054)$ & $(0.053)$ \\
\hline \multirow[t]{2}{*}{ Nonwage/1000 } & -0.070 & -0.070 & -0.070 \\
\hline & $(0.001)$ & $(0.001)$ & $(0.001)$ \\
\hline \multirow[t]{2}{*}{ Dummy ${ }_{\text {Round6 }}$} & 0.208 & 0.212 & 0.211 \\
\hline & $(0.076)$ & $(0.074)$ & $(0.075)$ \\
\hline \multirow[t]{2}{*}{ Dummy Round7 } & 0.176 & 0.179 & 0.179 \\
\hline & $(0.061)$ & $(0.060)$ & $(0.060)$ \\
\hline \multirow[t]{2}{*}{ Dummy ${ }_{\text {Round8 }}$} & 0.053 & 0.056 & 0.055 \\
\hline & $(0.032)$ & $(0.032)$ & $(0.032)$ \\
\hline Alcohol & --- & $\begin{array}{c}0.022 \\
(0.012)\end{array}$ & --- \\
\hline Drinks every day & $\begin{array}{l}-0.179 \\
(0.096)\end{array}$ & --- & --- \\
\hline \multirow[t]{2}{*}{ Drinks 4-6 times/week } & 0.041 & --- & --- \\
\hline & $(0.070)$ & & \\
\hline \multirow[t]{2}{*}{ Drinks 2-3 times/week } & 0.036 & --- & --- \\
\hline & $(0.033)$ & & \\
\hline \multirow[t]{2}{*}{ Drinks once/week } & 0.026 & --- & --- \\
\hline & $(0.022)$ & & \\
\hline \multirow[t]{2}{*}{ Drinks 2-3 times/month } & 0.043 & --- & --- \\
\hline & $(0.015)$ & & \\
\hline \multirow[t]{2}{*}{ Once/month } & 0.014 & --- & --- \\
\hline & $(0.014)$ & & \\
\hline \multirow[t]{2}{*}{ Ln(Ethanol) } & --- & --- & 0.007 \\
\hline & & & $(0.004)$ \\
\hline \multirow[t]{2}{*}{$\operatorname{Ln}(\text { Ethanol })^{2}$} & --- & --- & -0.001 \\
\hline & & & $(0.002)$ \\
\hline Number of Observations & 5,528 & 5,528 & 5,528 \\
\hline $\mathrm{R}^{2}$ & 0.752 & 0.752 & 0.623 \\
\hline
\end{tabular}

${ }^{\mathrm{a}}$ Standard errors are in parentheses. 
Table 10

Fixed-effects Estimates of Log(Wage) Equation for Males ${ }^{\text {a }}$

\begin{tabular}{|c|c|c|c|}
\hline Variable & Model One & Model Two & Model Three \\
\hline \multirow[t]{2}{*}{ Constant } & 9.062 & 8.683 & 8.229 \\
\hline & $(6.214)$ & $(6.214)$ & (6.214) \\
\hline \multirow[t]{2}{*}{ Experience } & 0.000 & 0.000 & 0.000 \\
\hline & $(0.014)$ & $(0.014)$ & $(0.014)$ \\
\hline \multirow[t]{2}{*}{ Experience $^{2} / 100$} & 0.011 & 0.011 & 0.010 \\
\hline & $(0.050)$ & $(0.050)$ & $(0.050)$ \\
\hline \multirow[t]{2}{*}{ Never Married } & 0.019 & 0.016 & 0.016 \\
\hline & $(0.239)$ & $(0.238)$ & $(0.239)$ \\
\hline \multirow[t]{2}{*}{ Married } & 0.083 & 0.067 & 0.063 \\
\hline & $(0.228)$ & $(0.226)$ & $(0.227)$ \\
\hline \multirow[t]{2}{*}{ Divorced } & 0.115 & 0.085 & 0.074 \\
\hline & $(0.290)$ & $(0.288)$ & $(0.288)$ \\
\hline \multirow[t]{2}{*}{ Health 1} & 0.964 & 0.985 & 0.970 \\
\hline & $(0.893)$ & $(0.890)$ & $(0.890)$ \\
\hline \multirow[t]{2}{*}{ Health 2} & 0.832 & 0.836 & 0.820 \\
\hline & $(0.866)$ & $(0.863)$ & $(0.863)$ \\
\hline \multirow{2}{*}{ Health 3} & 0.797 & 0.804 & 0.789 \\
\hline & $(0.864)$ & $(0.861)$ & $(0.861)$ \\
\hline \multirow[t]{2}{*}{ Health 4} & 0.783 & 0.787 & 0.768 \\
\hline & $(0.866)$ & $(0.864)$ & $(0.864)$ \\
\hline \multirow[t]{2}{*}{ Occupation 1} & 0.061 & 0.064 & 0.063 \\
\hline & $(0.179)$ & $(0.178)$ & $(0.178)$ \\
\hline \multirow[t]{2}{*}{ Occupation 2} & -0.240 & -0.234 & -0.231 \\
\hline & $(0.166)$ & $(0.165)$ & $(0.165)$ \\
\hline \multirow{2}{*}{ Occupation 3} & -0.100 & -0.095 & -0.095 \\
\hline & $(0.144)$ & $(0.141)$ & $(0.141)$ \\
\hline \multirow[t]{2}{*}{ Occupation 4} & -0.507 & -0.483 & -0.488 \\
\hline & $(0.284)$ & $(0.282)$ & $(0.282)$ \\
\hline \multirow{2}{*}{ Occupation 5} & -0.092 & -0.092 & -0.087 \\
\hline & $(0.187)$ & $(0.187)$ & $(0.187)$ \\
\hline \multirow[t]{2}{*}{ Occupation 6} & -0.020 & -0.020 & -0.020 \\
\hline & $(0.103)$ & $(0.103)$ & $(0.103)$ \\
\hline \multirow[t]{2}{*}{ Dummy $_{\text {Round6 }}$} & -0.962 & -0.957 & -0.942 \\
\hline & $(0.752)$ & $(0.710)$ & $(0.711)$ \\
\hline \multirow[t]{2}{*}{ Dummy $y_{\text {Round } 7}$} & -0.931 & -0.899 & -0.855 \\
\hline & $(0.608)$ & $(0.576)$ & $(0.576)$ \\
\hline \multirow{2}{*}{ Dummy } & -0.825 & -0.809 & -0.787 \\
\hline & $(0.306)$ & $(0.290)$ & $(0.290)$ \\
\hline \multirow[t]{2}{*}{ Alcohol } & --- & 0.209 & --- \\
\hline & & $(0.083)$ & \\
\hline Every day & $\begin{array}{c}0.243 \\
(0.205)\end{array}$ & --- & --- \\
\hline 4-6 times/week & $\begin{array}{c}0.325 \\
(0.171)\end{array}$ & --- & --- \\
\hline 2-3 times/week & $\begin{array}{c}0.187 \\
(0.116)\end{array}$ & --- & --- \\
\hline
\end{tabular}




\begin{tabular}{lccc} 
Once/week & 0.195 & --- & -- \\
& $(0.101)$ & & -- \\
$2-3$ times/month & 0.251 & -- & \\
& $(0.092)$ & & -- \\
Once/month & 0.149 & -- & 0.105 \\
& $(0.104)$ & --- & $(0.054)$ \\
Ln(Ethanol) & --- & -0.012 \\
Ln(Ethanol) & & -- & $(0.010)$ \\
\hline Number of & --- & 1,894 & 1,894 \\
Observations & 1,894 & & 0.770 \\
$\mathrm{R}^{2}$ & 0.771 & 0.770 & \\
\hline${ }^{\mathrm{a}}$ Standard errors are in parentheses. & &
\end{tabular}


Table 11

Fixed-effects Estimates of Log(Wage) Equation for Females a

\begin{tabular}{|c|c|c|c|}
\hline Variable & Model One & Model Two & Model Three \\
\hline \multirow[t]{2}{*}{ Constant } & 5.039 & 4.582 & 5.287 \\
\hline & $(6.208)$ & $(6.190)$ & (6.189) \\
\hline \multirow[t]{2}{*}{ Experience } & 0.002 & 0.003 & 0.004 \\
\hline & $(0.011)$ & $(0.011)$ & $(0.011)$ \\
\hline \multirow[t]{2}{*}{ Experience $^{2} / 100$} & -0.036 & -0.037 & -0.041 \\
\hline & $(0.041)$ & $(0.040)$ & $(0.041)$ \\
\hline \multirow[t]{2}{*}{ Never Married } & 0.242 & 0.227 & 0.231 \\
\hline & $(0.239)$ & $(0.238)$ & $(0.238)$ \\
\hline \multirow[t]{2}{*}{ Married } & 0.278 & 0.268 & 0.272 \\
\hline & $(0.149)$ & $(0.147)$ & $(0.148)$ \\
\hline \multirow[t]{2}{*}{ Divorced } & 0.232 & 0.222 & 0.227 \\
\hline & $(0.180)$ & $(0.180)$ & $(0.180)$ \\
\hline \multirow{2}{*}{ Health 1} & -0.676 & -0.688 & -0.652 \\
\hline & $(0.427)$ & $(0.426)$ & $(0.427)$ \\
\hline \multirow[t]{2}{*}{ Health 2} & -0.580 & -0.593 & -0.576 \\
\hline & $(0.312)$ & $(0.311)$ & $(0.312)$ \\
\hline \multirow{2}{*}{ Health 3} & -0.507 & -0.520 & -0.503 \\
\hline & $(0.307)$ & $(0.306)$ & $(0.306)$ \\
\hline \multirow[t]{2}{*}{ Health 4} & -0.731 & -0.743 & -0.730 \\
\hline & $(0.307)$ & $(0.306)$ & $(0.306)$ \\
\hline \multirow[t]{2}{*}{ Occupation 1} & -0.018 & -0.020 & -0.016 \\
\hline & $(0.175)$ & $(0.175)$ & $(0.175)$ \\
\hline \multirow{2}{*}{ Occupation 2} & -0.064 & -0.069 & -0.063 \\
\hline & $(0.129)$ & $(0.128)$ & $(0.129)$ \\
\hline \multirow{2}{*}{ Occupation 3} & 0.003 & 0.000 & -0.002 \\
\hline & $(0.112)$ & $(0.111)$ & $(0.111)$ \\
\hline \multirow[t]{2}{*}{ Occupation 4} & 0.180 & 0.173 & 0.176 \\
\hline & $(0.119)$ & $(0.118)$ & $(0.118)$ \\
\hline \multirow{2}{*}{ Occupation 5} & -0.193 & -0.192 & -0.191 \\
\hline & $(0.124)$ & $(0.123)$ & $(0.123)$ \\
\hline \multirow[t]{2}{*}{ Occupation 6} & 0.094 & 0.097 & 0.103 \\
\hline & $(0.179)$ & $(0.179)$ & $(0.179)$ \\
\hline \multirow[t]{2}{*}{ Dummy $_{\text {Round6 }}$} & -0.250 & -0.243 & -0.268 \\
\hline & $(0.715)$ & $(0.713)$ & $(0.713)$ \\
\hline \multirow{2}{*}{ Dummy $_{\text {Round } 7}$} & -0.132 & -0.130 & -0.148 \\
\hline & $(0.573)$ & $(0.571)$ & $(0.571)$ \\
\hline \multirow{2}{*}{ Dummy } & -0.335 & -0.333 & -0.342 \\
\hline & $(0.289)$ & $(0.288)$ & $(0.288)$ \\
\hline \multirow[t]{2}{*}{ Alcohol } & --- & 0.095 & --- \\
\hline & & $(0.049)$ & \\
\hline Every day & $\begin{array}{c}0.178 \\
(0.541)\end{array}$ & --- & --- \\
\hline \multirow[t]{2}{*}{ 4-6 times/week } & -0.049 & --- & --- \\
\hline & $(0.332)$ & & \\
\hline 2-3 times/week & $\begin{array}{c}0.127 \\
(0.136)\end{array}$ & --- & --- \\
\hline
\end{tabular}




\begin{tabular}{lccc} 
Once/week & 0.148 & --- & --- \\
& $(0.086)$ & & -- \\
$2-3$ times/month & 0.100 & --- & \\
& $(0.061)$ & & -- \\
Once/month & 0.086 & --- & 0.065 \\
& $(0.054)$ & -- & $(0.033)$ \\
Ln(Ethanol) & --- & --- & -0.013 \\
Ln(Ethanol) & & & $0.010)$ \\
\hline Number of & --- & 2,831 & 2,831 \\
Observations & 2,831 & & 0.716 \\
$\mathrm{R}^{2}$ & 0.716 & &
\end{tabular}

${ }^{\mathrm{a}}$ Standard errors are in parentheses. 


\section{IZA Discussion Papers}

\begin{tabular}{|c|c|c|c|c|}
\hline No. & Author(s) & Title & Area & Date \\
\hline 417 & J. Wagner & $\begin{array}{l}\text { Taking a Second Chance: } \\
\text { Entrepreneurial Restarters in Germany }\end{array}$ & 1 & $01 / 02$ \\
\hline 418 & $\begin{array}{l}\text { M. Frölich } \\
\text { P. A. Puhani }\end{array}$ & $\begin{array}{l}\text { Immigration and Heterogeneous Labor in } \\
\text { Western Germany: A Labor Market } \\
\text { Classification Based on Nonparametric } \\
\text { Estimation }\end{array}$ & 2 & $01 / 02$ \\
\hline 419 & $\begin{array}{l}\text { P. Frijters } \\
\text { J. P. Haisken-DeNew } \\
\text { M. A. Shields }\end{array}$ & $\begin{array}{l}\text { The Value of Reunification in Germany: } \\
\text { An Analysis of Changes in Life Satisfaction }\end{array}$ & 6 & $01 / 02$ \\
\hline 420 & $\begin{array}{l}\text { Å. Rosén } \\
\text { E. Wasmer }\end{array}$ & $\begin{array}{l}\text { Higher Education Levels, Firms' Outside Options } \\
\text { and the Wage Structure }\end{array}$ & 1 & $01 / 02$ \\
\hline 421 & P. Manzini & Divide et Impera: Negotiating with a Stakeholder & 6 & $02 / 02$ \\
\hline 422 & $\begin{array}{l}\text { J. T. Addison } \\
\text { L. Bellmann } \\
\text { C. Schnabel } \\
\text { J. Wagner }\end{array}$ & $\begin{array}{l}\text { The Long Awaited Reform of the German Works } \\
\text { Constitution Act }\end{array}$ & 6 & $02 / 02$ \\
\hline 423 & $\begin{array}{l}\text { E. Feess } \\
\text { G. Muehlheusser }\end{array}$ & Transfer Fee Regulations in European Football & 1 & $02 / 02$ \\
\hline 424 & $\begin{array}{l}\text { F. Büchel } \\
\text { M. van Ham }\end{array}$ & $\begin{array}{l}\text { Overeducation, Regional Labour Markets and } \\
\text { Spatial Flexibility }\end{array}$ & 3 & $02 / 02$ \\
\hline 425 & F. Büchel & $\begin{array}{l}\text { Successful Apprenticeship-to-Work Transitions: } \\
\text { On the Long-Term Change in Significance of the } \\
\text { German School-Leaving Certificate }\end{array}$ & 3 & $02 / 02$ \\
\hline 426 & $\begin{array}{l}\text { J. Hartog } \\
\text { W. P. M. Vijverberg }\end{array}$ & $\begin{array}{l}\text { Do Wages Really Compensate for Risk Aversion } \\
\text { and Skewness Affection? }\end{array}$ & 5 & $02 / 02$ \\
\hline 427 & D. Del Boca & $\begin{array}{l}\text { The Effect of Child Care and Part Time } \\
\text { Opportunities on Participation and Fertility } \\
\text { Decisions in Italy }\end{array}$ & 6 & $02 / 02$ \\
\hline 428 & D. Del Boca & $\begin{array}{l}\text { Mothers, Fathers and Children after Divorce: } \\
\text { The Role of Institutions }\end{array}$ & 6 & $02 / 02$ \\
\hline 429 & $\begin{array}{l}\text { S. Anger } \\
\text { J. Schwarze }\end{array}$ & $\begin{array}{l}\text { Does Future PC Use Determine Our Wages } \\
\text { Today? Evidence from German Panel Data }\end{array}$ & 5 & $02 / 02$ \\
\hline 430 & $\begin{array}{l}\text { J. Schwarze } \\
\text { M. Härpfer }\end{array}$ & $\begin{array}{l}\text { Are People Inequality Averse, and Do They } \\
\text { Prefer Redistribution by the State? Evidence } \\
\text { From German Longitudinal Data on Life } \\
\text { Satisfaction }\end{array}$ & 3 & $02 / 02$ \\
\hline 431 & $\begin{array}{l}\text { M. Fertig } \\
\text { C. M. Schmidt }\end{array}$ & $\begin{array}{l}\text { The Perception of Foreigners and Jews in } \\
\text { Germany - A Structural Analysis of a Large } \\
\text { Opinion Survey }\end{array}$ & 6 & $02 / 02$ \\
\hline 432 & E. Tekin & $\begin{array}{l}\text { Employment, Wages, and Alcohol Consumption } \\
\text { in Russia: Evidence from Panel Data }\end{array}$ & 4 & $02 / 02$ \\
\hline
\end{tabular}

